\title{
Volatilized and Condensed Sb- and As-Bearing Phases Produced During Roasting of Cu-Rich Complex Concentrate in Nitrogen Atmosphere with Oxygen in Traces
}

\author{
PANDE NISHANT PRASAD, ANDREAS LENNARTSSON, and CAISA SAMUELSSON
}

\begin{abstract}
A Cu-rich complex sulpfide concentrate (containing $\mathrm{Sb}$ as sulphosalts and gudmundite, and $\mathrm{As}$ as arsenopyrite) is roasted in Nitrogen atmosphere carrying traces of oxygen $\left(\mathrm{p}^{\mathrm{O}_{2}} \approx 10^{-5.3} \mathrm{bar}\right)$. In situ measurements through QMS indicated that the volatilized species are mainly elemental sulfur, $\mathrm{S}_{2}(\mathrm{~g})$, and gaseous sulfur oxides. Sb- and As-bearing volatilized species could not be detected, owing to their low concentrations in the gas phase. Characterization studies through XRD and SEM-EDS confirmed that the condensates collected at room temperature during the roasting experiments comprised of (1) cyclo-octa sulfur, $\mathrm{S}_{8}(\mathrm{~s})$ and polysulfur oxides, $\mathrm{S}_{n-x} \mathrm{O}_{x}(\mathrm{~s})$; (2) amorphous trisulfides of $\mathrm{Sb}$ and $\mathrm{As}$; (3) and cubic crystalline trioxides of $\mathrm{Sb}$ and As. The solid phases in the condensate were found to be fine-sized (sub-micronic) and widely intermixed. Consequently, quantification of the solid phases in the condensates through direct measurement techniques like QEMSCAN was not possible. A novel approach of partial quantification of solid phases in the condensate through a stochastic model-based calculation approach is also presented. The model results suggested the occurrence of vapor-phase complexation of sulfides of $\mathrm{Sb}$ and $\mathrm{As}$ in the gas phase. Additional attributes of the volatilized species could be determined through a thermodynamic equilibrium calculation showing that the formation of the complex oxides, $\mathrm{As}_{4-n} \mathrm{Sb}_{n} \mathrm{O}_{6}(\mathrm{~g})$, would be negligible compared to that of the complex sulfides, $\mathrm{As}_{4-n} \mathrm{Sb}_{n} \mathrm{~S}_{6}(\mathrm{~g})$.
\end{abstract}

https://doi.org/10.1007/s11663-021-02154-1

(C) The Author(s) 2021

\section{INTRODUCTION}

THE objectives of roasting the concentrates at a copper-making facility are drying and enrichment of incoming concentrate, partial oxidation of iron bearing phases, and volatilization of deleterious elements (such as $\mathrm{Sb}, \mathrm{As}$ ) for further pyrometallurgical extraction. In the recent times, the roasting unit became optional with the advent of continuous smelting and converting technologies such as Flash, Noranda, Isasmelt, and Ausmelt smelting. Nevertheless, the significance of roasting has again renewed, with the primary focus on volatilization of elements such as $\mathrm{Sb}$ and As, owing to the depletion of clean deposits and the increased production of complex concentrates.

PANDE NISHANT PRASAD, ANDREAS LENNARTSSON, and CAISA SAMUELSSON are with the Luleå Tekniska Universitet, 97187 Luleå, Sweden. Contact e-mail: pande.nishant.prasad@ltu.se

Manuscript submitted November 12, 2020; accepted March 15, 2021.

Article published online April 20, 2021.
There have been detailed studies evaluating the nature of Sb- and As-bearing volatilized and condensed species produced during roasting. The starting materials roasted in these studies were either pure compounds (As- and Sb-oxides and sulfides $)^{[1-4]}$ or dusts from non-ferrous pyrometallurgical processes, high in $\mathrm{Sb}$ and As contents. ${ }^{[5-8]}$ These studies highlighted the attribute of vapor-phase complexation of volatile species of $\mathrm{Sb}$ and As leading to the formation of complex gaseous oxides, $\mathrm{As}_{n} \mathrm{Sb}_{4-n} \mathrm{O}_{6}(\mathrm{~g})$ and sulfides, $\mathrm{As}_{n} \mathrm{Sb}_{4-n} \mathrm{~S}_{6}(\mathrm{~g}), n=1,2,3$. Thermodynamic data for the vapor-phase complex oxides, $\mathrm{As}_{n} \mathrm{Sb}_{4-n} \mathrm{O}_{6}(\mathrm{~g})(n=1,2,3)$, were determined by $\mathrm{Li}$ et al. ${ }^{[1]}$ These calculations were based on the exceptional property of zero heat of disproportionation reactions of these mixed oxide compounds ${ }^{[9,10]}$ and the results of vapor transport experiments using $\mathrm{As}_{2} \mathrm{O}_{3}(\mathrm{~s})$ and $\mathrm{Sb}_{2} \mathrm{O}_{3}(\mathrm{~s})$. However, for the sulfidic complexes, $\mathrm{As}_{n} \mathrm{Sb}_{4-n} \mathrm{~S}_{6}(\mathrm{~g})(n=1,2,3)$, thermodynamic data are available only for the species- $\mathrm{AsSb}_{3} \mathrm{~S}_{6}(\mathrm{~g}) .{ }^{[11]}$ Equilibrium calculations based on these thermodynamic datasets supported the experimental findings that the formation of these complex species of As and $\mathrm{Sb}$ in the vapor-phase would facilitate an increased Sb-volatilization. ${ }^{[8,12]}$ 
$\mathrm{Sb}$ and $\mathrm{As}$ form non-volatile oxide compounds at the oxidation potentials $\mathrm{p}^{\mathrm{O}_{2}}>10^{-10}$ bar and $\mathrm{p}^{\mathrm{O}_{2}}>10^{-5.35}$ bar respectively. ${ }^{[13]}$ Therefore, the volatilization of these elements from the sulfide concentrates during roasting have been studied in different controlled atmospheric environments. ${ }^{[14-22]}$ However, the properties of volatilized and condensed Sb- and As-bearing species emanating from the sulfide concentrates during roasting have been rarely studied. Also, the effect of simultaneous release of volatile species by the other minerals such as pyrite present in the concentrate (comprising of labile sulfur ${ }^{[23]}$ ) on the gas phase complexation behavior of $\mathrm{Sb}$ and As has not been investigated. It is important to bridge this knowledge gap in order to improve the volatilization of $\mathrm{As}$ and $\mathrm{Sb}$ in industrial conditions during roasting, especially when the concentrate blends with increased proportions of complex concentrates are processed for the $\mathrm{Cu}$ extraction.

In this article, the condensates collected from the laboratory-scale roasting experiments performed by Prasad et al. ${ }^{[24]}$ on polymetallic $\mathrm{Cu}$-rich sulfide concentrates will be analyzed for the identification of condensed species. The experiments in this preceding study were carried out in Nitrogen atmosphere having traces of oxygen $\left(\mathrm{O}_{2}<5\right.$ ppm, $\mathrm{H}_{2} \mathrm{O}<5$ ppm, $\mathrm{p}^{\mathrm{O}_{2}} \approx 10^{-5.3}$ bar $)$, representative of feebly oxidizing conditions in the gas phase. They concluded through a low-temperature roasting experiment on a concentrate high in both $\mathrm{Sb}$ and $\mathrm{As}$ (considered high in $\mathrm{As}$ and $\mathrm{Sb}$ based on the smelter penalty limits ${ }^{[25]}$ ) that substantial Sb-volatilization takes place from the mineral gudmundite (FeSbS), owing to its decomposition between $300{ }^{\circ} \mathrm{C}$ and $400{ }^{\circ} \mathrm{C}$ into pyrrhotite and metallic-Sb. However, the mechanism activating Sb-volatilization from metallic-Sb was not elaborated. The current work attempts to further elucidate this Sb-volatilization process. Thermodynamic assessments are performed for (1) the stability of possible $\mathrm{Sb}$ - and As-bearing gaseous species during roasting and (2) the likelihood of Sb-As vapor-phase complexation in such conditions.

Additionally, this current study will portray certain limitations in the detection of Sb- and As-bearing volatilized species from in situ analyses of the gas phase through Quadrupole Mass Spectrometer during roasting of the sulfide concentrates. Despite these limitations, significant attributes of $\mathrm{Sb}$ - and As-bearing gaseous species will be gauged through a novel stochastic model-based calculation approach. This model will also facilitate a certain degree of quantification of the identified condensed phases in the condensate collected during a roasting experiment.

\section{MATERIALS}

A Cu-rich polymetallic concentrate prepared by Minz et $a .^{[26]}$ from laboratory-scale flotation of crushed drilled core samples from the Rockliden deposit of Sweden was used in this study. The chemical composition of this concentrate is listed in Table I.
This concentrate is considered to be high in $\mathrm{Sb}$ and $\mathrm{As}$ based on the limits above which smelter penalties ${ }^{[25]}$ are generally imposed. The As-bearing mineral in the concentrate is arsenopyrite (FeAsS) and the Sb-bearing minerals are tetrahedrite $\left((\mathrm{Cu}, \mathrm{Ag}, \mathrm{Fe}, \mathrm{Zn})_{12} \mathrm{Sb}_{4} \mathrm{~S}_{13}\right)$, bournonite $\left(\mathrm{CuPbSbS}_{3}\right)$, and gudmundite $\left.(\mathrm{FeSbS}) .{ }^{24}\right]^{2}$

The initial concentrate and the roasted calcines obtained from the laboratory-scale roasting experiments (to be described in the upcoming Section III-A) were analyzed for their chemical compositions by ALS Global AB, Luleå. The samples were melted in $\mathrm{LiBO}_{2}$ and digested in $\mathrm{HNO}_{3} / \mathrm{HCl} / \mathrm{HF}$. The measurements were made using ICP-SFMS in accordance with SS EN ISO 17294-2: $2016^{[28]}$ and EPA method 200.8: 1994. ${ }^{[29]}$

\section{METHODS}

\section{A. Roasting Experiments in Vertical Tube Furnace}

The Rockliden S7574 concentrate was tested in a vertical tube furnace setup described previously by Prasad et al. ${ }^{[24]}$ The sample was introduced in the furnace and held in a cold chamber while the furnace heating was started. After the attainment of the desired furnace temperature, the sample was introduced in the hot zone. The furnace temperature was set higher than the aimed sample temperature, in accordance with the wall and center temperature relationship of this setup presented in a previous study by Prasad et al. ${ }^{[27]}$ For instance, the furnace temperature set-point was $404{ }^{\circ} \mathrm{C}$ when the aimed sample temperature was $350{ }^{\circ} \mathrm{C}$ in the Experiment ID 350-10. A controlled gas atmosphere was maintained from the beginning by introducing Nitrogen (Chemical Nitrogen 4.6 from AGA-Linde, Purity $\geq 99.996$ pct, $\mathrm{H}_{2} \mathrm{O} \leq 5 \mathrm{ppm}, \mathrm{O}_{2} \leq 5 \mathrm{ppm}$ ) as a carrier gas. Details of the experiments performed in this setup are listed in Table II.

Figure 1 presents a schematic of the vertical tube furnace used in this study. An optional water-cooled condensation plate was used in this apparatus for the Experiment IDs 700-1 and 350-10 to facilitate the partial condensation (at room temperature) of volatiles in the gas phase before leaving through the outlet. During the Experiment ID 350-10, the temperature was held at $350{ }^{\circ} \mathrm{C}$ for 10 hours, and a higher sample mass of $50 \mathrm{~g}$ was used to obtain sufficient amount of the condensates from this experiment for proper characterization.

\section{B. TGA-DTA-QMS Study}

The concentrate sample was also tested in a Netzsch STA 409 instrument (sensitivity $\pm 1 \mu \mathrm{g}$ ) to determine the mass loss and phase transformations during heating through Thermo-Gravimetric Analysis (TGA) and Differential Thermal Analysis (DTA), respectively. A Quadrupole Mass Spectrometer (QMS) connected to the thermo-gravimetric setup performed in situ analysis of the gas phase emanating from the sample. Quadstar 32-bit program was used to operate the mass 
Table I. Chemical Composition of the Cu-Rich Complex Polymetallic Concentrate Used in This Study

\begin{tabular}{lccccccccccc}
\hline Concentrate/Element (Wt Pct) & $\mathrm{Cu}$ & $\mathrm{Zn}$ & $\mathrm{Pb}$ & $\mathrm{Fe}$ & $\mathrm{Si}$ & $\mathrm{Mg}$ & $\mathrm{S}$ & $\mathrm{Ag}$ & $\mathrm{As}$ & $\mathrm{Sb}$ \\
\hline Rockliden S7574 & 13.8 & 8.4 & 5.2 & 25.1 & 0.3 & 0.1 & 31.4 & 0.03 & 0.74 & 1.36 \\
\hline
\end{tabular}

Data from Prasad et al..$^{[27]}$

Table II. Details of Laboratory-Scale Roasting Experiments With the Rockliden S7574 Concentrate in Vertical Tube Furnace

\begin{tabular}{lccccc}
\hline Experiment ID & $\begin{array}{c}\text { Carrier Gas; } \\
\text { Flow Rate, L/min }\end{array}$ & $T,{ }^{\circ} \mathrm{C}$ & Holding Time, min. & Sample Initial Weight, g & Sample Initial Size Fraction \\
\hline $200-1$ & $\mathrm{~N}_{2} ; 5$ & 200 & 70 & 10 & $38-53 \mu \mathrm{m}$ \\
$300-1$ & $\mathrm{~N}_{2} ; 5$ & 300 & 70 & 10 & $38-53 \mu \mathrm{m}$ \\
$400-1$ & $\mathrm{~N}_{2} ; 5$ & 400 & 70 & 10 & $38-53 \mu \mathrm{m}$ \\
$500-1$ & $\mathrm{~N}_{2} ; 5$ & 500 & 70 & 10 & $38-53 \mu \mathrm{m}$ \\
$600-1$ & $\mathrm{~N}_{2} ; 5$ & 600 & 70 & 10 & $38-53 \mu \mathrm{m}$ \\
$700-1$ & $\mathrm{~N}_{2} ; 5$ & 700 & 70 & 10 & $38-53 \mu \mathrm{m}$ \\
$350-10$ & $\mathrm{~N}_{2} ; 2$ & 350 & 600 & 50 & below 38 $\mu \mathrm{m}$ \\
\hline
\end{tabular}

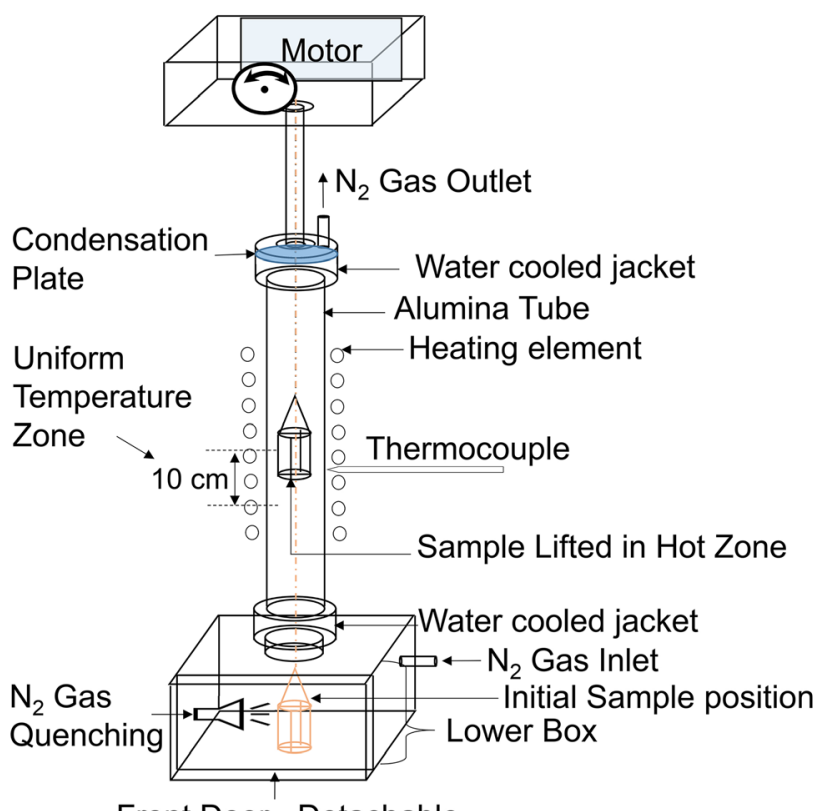

Front Door - Detachable

Fig. 1-Vertical tube furnace for roasting of concentrate. Adapted from Prasad et al. ${ }^{[24]}$

spectrometer. Details of this equipment assembly are mentioned in Ahmed et al. ${ }^{[30]}$ The experiments performed in this setup are listed in Table III.

The carrier gas used in these thermo-gravimetric experiments was again Chemical Nitrogen 4.6 (additionally containing $\left.\mathrm{H}_{2} \mathrm{O}(\mathrm{g}) \leq 5 \mathrm{ppm}, \mathrm{O}_{2}(\mathrm{~g}) \leq 5 \mathrm{ppm}\right)$. During the Experiment ID 1000-TG, the QMS was operated in Scanning Bargraph mode for the detection of gaseous species with mass-to-charge ratio $(\mathrm{m} / \mathrm{e})$ in a specified range between 1 and 300. In the Experiment ID 350-TG, the mode of QMS was Multiple Ion Detection
(MID). In this mode, the ion current measurements in QMS were performed only for a set of preassigned $m / e$ values.

Table IV presents the list of gaseous compounds intended for detection in the MID-mode of QMS. In case of the heteronuclear compounds of Sb and As, the $m /$ $e$ values were assigned for both molecular and ionic species (for instance, in case of $\mathrm{As}_{3} \mathrm{SbO}_{6}(\mathrm{~g}), \mathrm{m} /$ $e=442-443$ for its molecular form, and $\mathrm{m} /$ $e=426-428$ for its ionic form- $-\mathrm{As}_{3} \mathrm{SbO}_{5}^{+[2]}$ ). This was to increase the possibility of the detection of these complex gaseous species during the in situ measurements in QMS. The Sb- and As-bearing compounds listed in Table IV were those which were predicted to form during the volatilization process by a thermodynamic model, presented later in this article (Section V). Additionally, the two complex sulfide species- $\mathrm{As}_{3} \mathrm{SbS}_{6}(\mathrm{~g})$ and $\mathrm{As}_{2} \mathrm{Sb}_{2} \mathrm{~S}_{6}(\mathrm{~g})$, were included in this list based on the experimental evidences of their existence in the gas phase in the work of Mauser et al ${ }^{[2]}$ These two gaseous species were not estimated in the thermodynamic calculations due to unavailability of their thermodynamic data.

An important limitation of the QMS setup used in this work is that it cannot perform detection of species with $m / e>510$. Therefore, $m / e$ values for the compounds with high molecular weights- $\mathrm{AsSb}_{3} \mathrm{O}_{6}, \mathrm{As}_{2} \mathrm{Sb}_{2} \mathrm{~S}_{6}$, $\mathrm{AsSb}_{3} \mathrm{~S}_{6}, \mathrm{Sb}_{4} \mathrm{~S}_{3}$, and $\mathrm{Sb}_{4} \mathrm{O}_{6}$ could not be assigned for detection in the QMS (in the MID-mode) during the run of Experiment ID 350-TG (Table III).

\section{SEM/EDS Analysis}

Figure 2 shows the images of the condensate collected from the roasting Experiment ID 700-1 (Table II) in the vertical tube furnace, illustrating the physical appearance of the collected condensates from the roasting experiments in the vertical tube furnace. In both the Experiment IDs 
Table III. Details of the Experiments Performed in Thermogravimetry QMS Setup

Experiment ID

Experimental Conditions

1000-TG

$350-\mathrm{TG}$

Maximum temp., ${ }^{\circ} \mathrm{C}$

Measurements

Carrier gas; flow rate, $\mathrm{mL} / \mathrm{min}$

Heating/cooling rates, ${ }^{\circ} \mathrm{C} / \mathrm{min}$

Holding time at max. temp., $\mathrm{h}$

Sample wt, mg

QMS mode

$\begin{array}{ll}1000 & 350 \\ \text { TGA, DTA, QMS } & \text { TGA, QMS } \\ \mathrm{N}_{2} ; 100 & \mathrm{~N}_{2} ; 50 \\ 10 & 10 \\ 0 & 10 \\ 150 & 150 \\ \text { scanning bargraph } & \text { multiple ion detection (MID) }\end{array}$

Table IV. Gaseous Compounds and Corresponding Mass-to-Charge Ratio, $m / e$ Values Fed in the Multiple Ion Detection (MID) Mode of QMS

\begin{tabular}{|c|c|c|c|}
\hline Sl. No. & Gasous Compounds & Mol Wt (g/mol) & Mass-to-Charge Ratio in MID-Mode of QMS \\
\hline 1 & $\mathrm{As}_{3} \mathrm{SbO}_{6}$ & 443 & $426,427,428,442,443$ \\
\hline 2 & $\mathrm{As}_{2} \mathrm{Sb}_{2} \mathrm{O}_{6}$ & 489 & $472,473,474,475,476,489,490$ \\
\hline 3 & $\mathrm{AsSb}_{3} \mathrm{O}_{6}$ & 536 & $518^{*}, 519^{*}, 520^{*}, 521^{*}, 522^{*}, 523^{*}, 524^{*}, 536^{*}, 537^{*}$ \\
\hline 4 & $\mathrm{As}_{3} \mathrm{SbS}_{6}$ & 539 & $506,507,508,538^{*}, 539 *$ \\
\hline 5 & $\mathrm{As}_{2} \mathrm{Sb}_{2} \mathrm{~S}_{6}$ & 585 & $552^{*}, 553^{*}, 554^{*}, 556^{*}, 585^{*}, 586^{*}$ \\
\hline 6 & $\mathrm{AsSb}_{3} \mathrm{~S}_{6}$ & 632 & $598^{*}, 599^{*}, 600^{*}, 601^{*}, 602^{*}, 603^{*}, 604^{*}, 632^{*}, 633^{*}$ \\
\hline 7 & $\mathrm{Sb}_{2} \mathrm{~S}_{3}$ & 340 & 339,340 \\
\hline 8 & $\mathrm{Sb}_{2} \mathrm{~S}_{4}$ & 372 & 371,372 \\
\hline 9 & $\mathrm{Sb}_{4} \mathrm{~S}_{3}$ & 583 & $583^{*}, 584^{*}$ \\
\hline 10 & $\mathrm{As}_{4} \mathrm{~S}_{4}$ & 428 & 427,428 \\
\hline 11 & $\mathrm{AsS}$ & 107 & 106,107 \\
\hline 12 & $\mathrm{AsO}$ & 91 & 90,91 \\
\hline 13 & $\mathrm{SbS}$ & 154 & 153,154 \\
\hline 14 & $\mathrm{SbO}$ & 138 & 137,138 \\
\hline 15 & $\mathrm{As}_{4} \mathrm{O}_{6}$ & 396 & 395,396 \\
\hline 16 & $\mathrm{Sb}_{4} \mathrm{O}_{6}$ & 583 & $583^{*}, 584^{*}$ \\
\hline 17 & $\mathrm{~S}_{2}$ & 64 & 64 \\
\hline 18 & $\mathrm{SO}_{2}$ & 64 & 64 \\
\hline 19 & SO & 48 & 48 \\
\hline 20 & $\mathrm{O}_{2}$ & 32 & 32 \\
\hline
\end{tabular}

700-1 and 350-10, the collected condensates had soft and polymeric texture. Each condensate was subsequently crushed manually in a mortar under liquid Nitrogen into a fine powder. A portion of the crushed powder was mixed with liquid epoxy, and the solidified epoxy mount was polished and carbon coated. These epoxy mounts were analyzed in a Zeiss Merlin FEG SEM (Scanning Electron Microscope) together with an Oxford Instruments X-Max EDS (Energy-Dispersive X-ray Spectroscopy) detector. The EDS was operated by AZtec software. A working distance of $8.5 \mathrm{~mm}$, probe current of $500 \mathrm{pA}$, and accelerating voltage of $20 \mathrm{kV}$ were employed for operating the SEM-EDS. Beam calibration in EDS was done using pure copper. The elemental composition obtained from EDS measurements is reported in mol pct after normalization, ensuring the summation of the concentrations for all identified elements to be $100 \mathrm{~mol}$ pct.

\section{Powder XRD}

The left over amount of powdered condensates after epoxy-molding were analyzed with XRD. These measurements were performed in a PANalytical Empyrean $\mathrm{X}$-ray diffractometer in $\theta-\theta$ geometry using $\mathrm{Cu} \mathrm{K} \alpha$ radiation $(\lambda=0.154184 \mathrm{~nm})$, beam current of $40 \mathrm{~mA}$, $20 \mathrm{deg} \leq 2 \theta \leq 90 \mathrm{deg}$ with a step size of $0.026^{\circ} / \mathrm{s}$, and beam voltage of $45 \mathrm{mV}$. A PIXcel 3D detector was used. A shallow sample holder with zero/negligible background was used to hold the condensate powders during the measurement, as the obtained quantities of the condensate powders were smaller than the normal sample size for the XRD-measurement. The obtained XRD patterns were evaluated in HighScore Plus (v4.7, a software from PANalytical B.V., Almelo, The Netherlands) using the FIZ-NIST ICSD (Inorganic Crystal Structure Database) database, version 2015-1. 


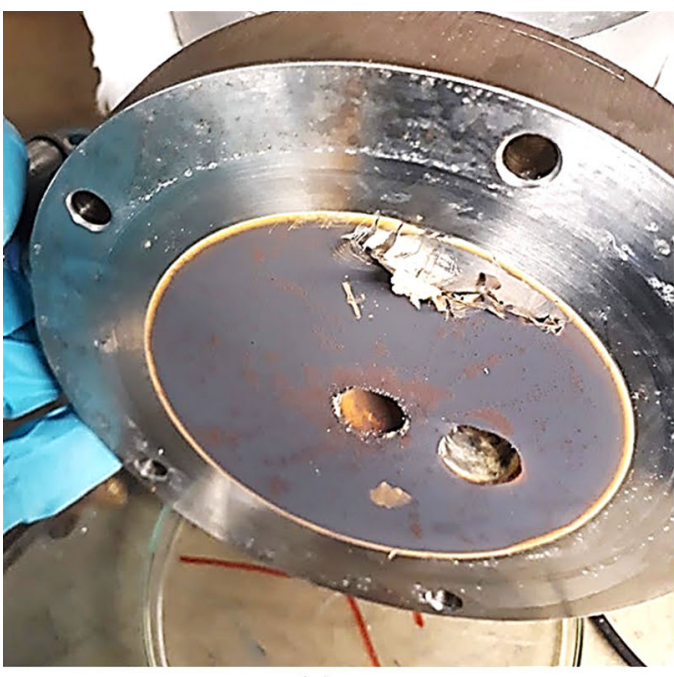

(a)

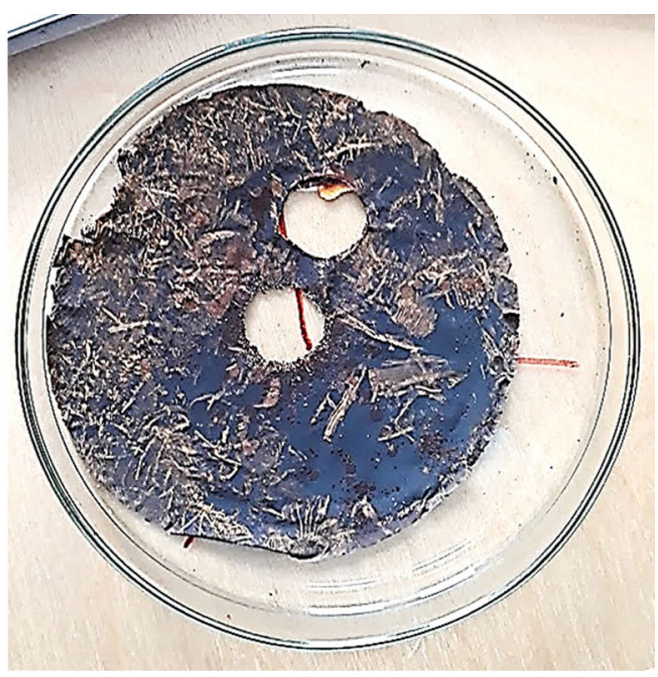

(b)

Fig. 2-Images of the condensate collected from the Experiment ID 700-1 of roasting Rockliden S7574 concentrate in the vertical tube furnace. (a) Condensate as-deposited on the water-cooled Condensation plate (shown in Fig. 1); (b) Condensate peeled-off from the condensation plate for further investigations, having soft, polymeric texture.

\section{EXPERIMENTAL RESULTS AND DISCUSSION}

\section{A. Evaluation of Volatilization During Roasting}

Results of the Experiment ID 1000-TG (Table III) in the TGA-DTA-QMS setup are presented in Figure 3. The highest ion current in QMS was measured for $m /$ $e=32$, representing $\mathrm{O}_{2}(\mathrm{~g})$. The nearly constant ion current for this $m / e$ value over the entire heating cycle is also suggestive of it being the trace oxygen in the carrier Nitrogen gas. QMS detected a gaseous species with $m /$ $e=64$ as the predominant volatilized compound above $400{ }^{\circ} \mathrm{C} . m / e=64$ may represent either $\mathrm{S}_{2}(\mathrm{~g})$ or $\mathrm{SO}_{2}(\mathrm{~g})$, owing to their similarity in molecular weight $(\approx 64)$. $\mathrm{SO}_{2}(\mathrm{~g})$ would evolve through the exothermic oxidation of sulfide minerals like chalcopyrite and pyrite. However, the peaks in the DTA curve corresponding to the QMS peaks for $m / e=64$ are endothermic. Therefore, $\mathrm{S}_{2}(\mathrm{~g})$ with $m / e=64$ is the predominant volatilized species, which is expected to be emanating from the pyrolysis (endothermic process) of chalcopyrite ${ }^{[31]}$ and pyrite $^{[23]}$. Simultaneous detection of $\mathrm{SO}(\mathrm{g})$ corresponding to $m / e=48$ further suggests that the trace oxygen in the carrier Nitrogen partially oxidizes the $\mathrm{S}_{2}(\mathrm{~g})$. However, the QMS does not detect any Sb- or As-bearing gaseous species during this experimental run.

Figure 4 presents the molar quantities $\Delta \mathrm{S}(\mathrm{mol})$, $\Delta \mathrm{Sb}(\mathrm{mol})$, and $\Delta \mathrm{As}(\mathrm{mol})$ of the elements volatilized during the roasting experiments on Rockliden S7574 concentrate in the vertical tube furnace at different temperatures between $200{ }^{\circ} \mathrm{C}$ and $700{ }^{\circ} \mathrm{C}$ (experimental details in Table II). Data in this plot are obtained from the chemical analyses and weights of the initial concentrate and the roasted calcines, presented in an earlier work by Prasad et al. ${ }^{[24]}$ Evidently, at every temperature, the moles of $\mathrm{S}$ volatilized are approximately two order of magnitude higher than the quantities of $\mathrm{Sb}$ and $\mathrm{As}$ volatilized. This implies that the concentration of the

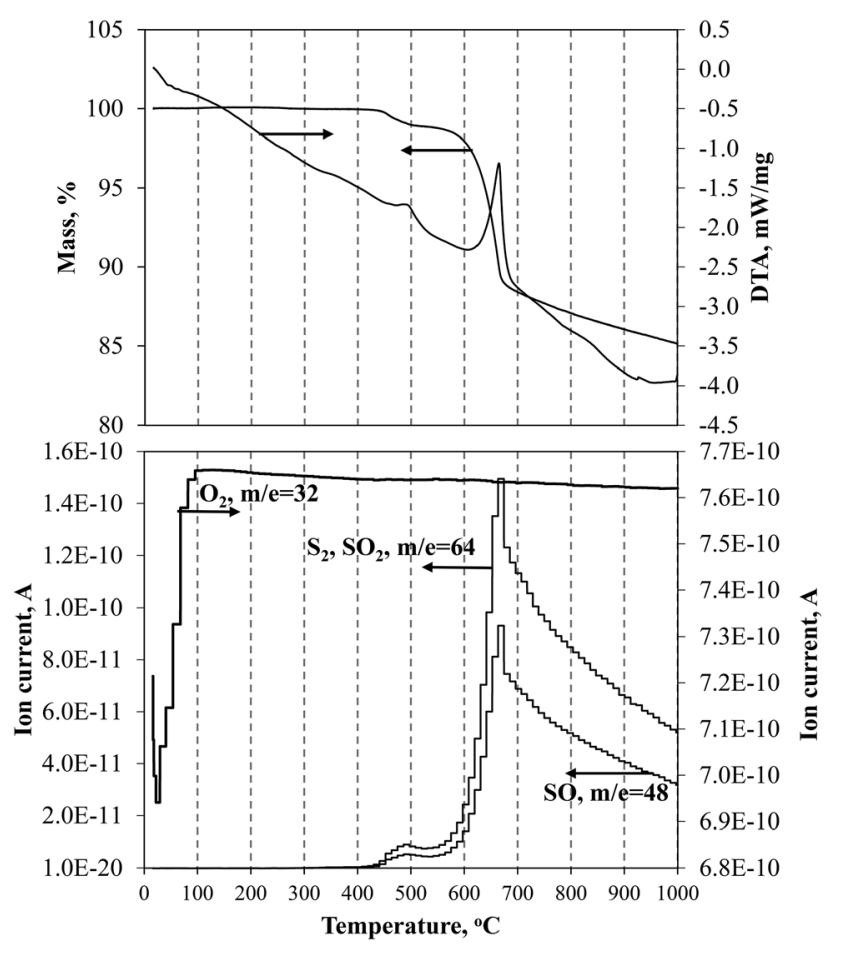

Fig. 3-TGA-DTA (top graph) and QMS (lower graph) measurements during the heating of Rockliden S7574 concentrate up to $1000{ }^{\circ} \mathrm{C}$ in Nitrogen atmosphere containing traces of oxygen $\left(\mathrm{H}_{2} \mathrm{O} \leq 5 \mathrm{ppm}, \mathrm{O}_{2} \leq 5 \mathrm{ppm}\right)$. Both the graphs have common $x$-axis of temperature.

volatilized Sb- and As-bearing gaseous species in the gas phase would be comparatively much lower than that of $\mathrm{S}_{2}(\mathrm{~g})$. Additionally, there will be a significant dilution owing to a constant flow of carrier gas $\left(\mathrm{N}_{2}\right)$, thereby explaining the non-detection of Sb- and As- volatiles by the QMS (Figure 3) during the run of Experiment ID 1000-TG in the TGA-DTA-QMS setup. 


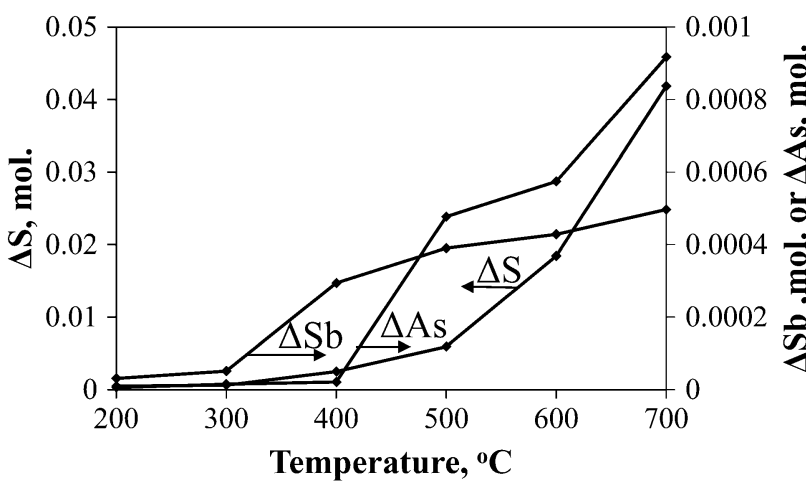

Fig. 4-Moles of elements ( $\mathrm{Sb}, \mathrm{As}, \mathrm{S}$ ) volatilized from $10 \mathrm{~g}$ of Rockliden S7574 concentrate in the roasting experiments in the vertical tube furnace at different temperatures between $200{ }^{\circ} \mathrm{C}$ and $700{ }^{\circ} \mathrm{C}$ in Nitrogen atmosphere.

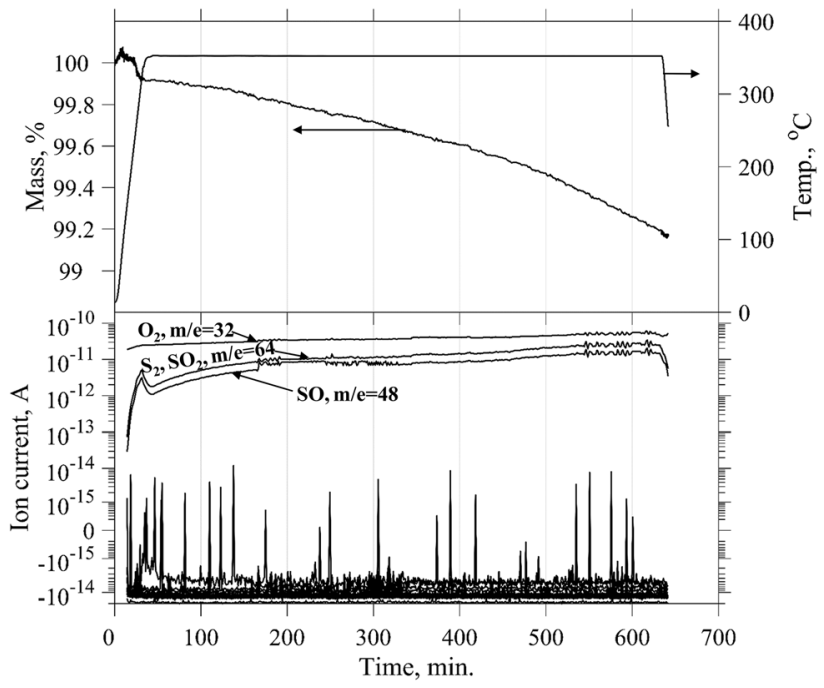

Fig. 5-TGA-mass vs. time and temperature vs. time from TGA-DTA measurements (top graph); QMS measurements vs. time (lower graph) for heating Rockliden S7574 concentrate upto $350{ }^{\circ} \mathrm{C}$ and holding for $10 \mathrm{~h}$ in Nitrogen atmosphere containing traces of oxygen $\left(\mathrm{H}_{2} \mathrm{O} \leq 5 \mathrm{ppm}, \mathrm{O}_{2} \leq 5 \mathrm{ppm}\right)$. Both the graphs having common $x$-axis of time (min). Data of QMS being in a wide range comprising of both negative and positive values are plotted in a symmetric logarithmic scale. ${ }^{[32]}$ Only the QMS curves with consistent positive ion current measurements are labeled for the gaseous specie corresponding to the $m / e$ value.

Figure 4 in addition shows that noticeable Sb-volatilization started above $300{ }^{\circ} \mathrm{C}$. Also, in the QMS measurements in Figure 3, $\mathrm{S}_{2}(\mathrm{~g})$ concentration in the gas phase was low below $400{ }^{\circ} \mathrm{C}$. Based on these two observations, an experiment was planned in the TGA-QMS setup for heating the concentrate in Nitrogen atmosphere upto a temperature of $350{ }^{\circ} \mathrm{C}$ (midway between $300{ }^{\circ} \mathrm{C}$ and $400{ }^{\circ} \mathrm{C}$ ), and holding at this temperature for 10 hours under a reduced Nitrogen flow of $50 \mathrm{~mL} / \mathrm{min}$ (compared to $100 \mathrm{~mL} / \mathrm{min}$ in the Experiment ID 1000-TG, Table III). The possibility of detection of Sb- and As-bearing phases in the QMS measurement was expected to increase due to likely low $\mathrm{S}_{2}(\mathrm{~g})$ volatilization at $350^{\circ} \mathrm{C}$.
Figure 5 presents the results of TGA and QMS measurements in the experiment at $350{ }^{\circ} \mathrm{C}$ (Experiment ID 350-TG in Table III). The QMS was set to measure ion currents for the selected $m / e$ values $\leq 510$ mentioned in Table IV. The concentrate experienced a total mass loss of approximately 0.8 pct in this experiment. The ion current measurements through QMS were in a wide range comprising of both positive and negative values. Consequently, a symmetric logarithmic scale developed by Webber ${ }^{[32]}$ was used in Figure 5 (the transformation involved is $y=\operatorname{sgn}(x) \cdot \log _{10}(1+|(x / C)|)$, 'sgn' is the Signum function, $C=15.7)$ for the plotting of these widely scattered positive and negative ion current values. The QMS measurements could again clearly detect only $\mathrm{O}_{2}(\mathrm{~g})$ and the sulfur bearing $\mathrm{S}_{2}(\mathrm{~g})$ and $\mathrm{SO}(\mathrm{g})$ in the gas phase at this low temperature. The ion currents measured for rest of the $\mathrm{m} / \mathrm{e}$ values corresponding to different $\mathrm{Sb}$ - and As-bearing species were in a narrow band of negative values below $-10^{-15} \mathrm{~A}$. Tamura et al. ${ }^{[33]}$ associated such negative ion current values to the offset error of ammeter in QMS, essentially implying non-detection. However, sporadic positive ion current values are also recorded for these $m / e$ values in Figure 5, suggesting that the Sb- and As- bearing species did exist in the gas phase, but in very low concentrations. This experiment, therefore, demonstrated the limitations in the in situ detection of the Sb- and As-bearing volatilized species through QMS during the roasting of $\mathrm{Cu}$-rich sulfide concentrates in inert atmosphere.

\section{B. Characterization of the Collected Condensates}

Figure 6 presents the XRD pattern of the condensate collected during the Experiment ID 700-1 (Table II) by roasting Rockliden S7574 concentrate at $700{ }^{\circ} \mathrm{C}$ in the vertical tube furnace. It shows that the condensate primarily comprises of elemental sulfur in the form of cyclo-octasulfur, $\mathrm{S}_{8}(\mathrm{~s})$.

Notably, similar to the failure in detecting Sb- and As-bearing species in the gas phase during measurement by the QMS, Sb and As compounds in the solid condensate could again not be identified through XRD. This was expected based on the fact that S-volatilization was two orders of magnitude higher than the quantities of $\mathrm{Sb}$ - and As-volatilization as shown in Figure 4.

XRD pattern of the condensate generated during the Experiment ID 350-10 of roasting the Rockliden S7574 concentrate at $350{ }^{\circ} \mathrm{C}$ is presented in Figure 7(a). It suggests that this condensate primarily comprises of $\mathrm{Sb}-$ and As-bearing compounds, unlike the elemental sulfur-rich condensate (Figure 6) from the roasting experiment at $700{ }^{\circ} \mathrm{C}$. Secondly, the XRD pattern indicates that instead of the sulfides, expected to form during the roasting of sulfide concentrates in Nitrogen atmosphere, the condensate comprises of oxides. Most of the peaks in Figure 7(a) match with both $\mathrm{As}_{2} \mathrm{O}_{3}$ (cubic) and $\mathrm{Sb}_{2} \mathrm{O}_{3}$ (cubic) phases. Clearly, the traces of oxygen in the Nitrogen flow have contributed to the oxidation of $\mathrm{Sb}$ - and As-bearing volatiles. Figure 7(b) is the stem-plot showing only the peak intensities of the measured 


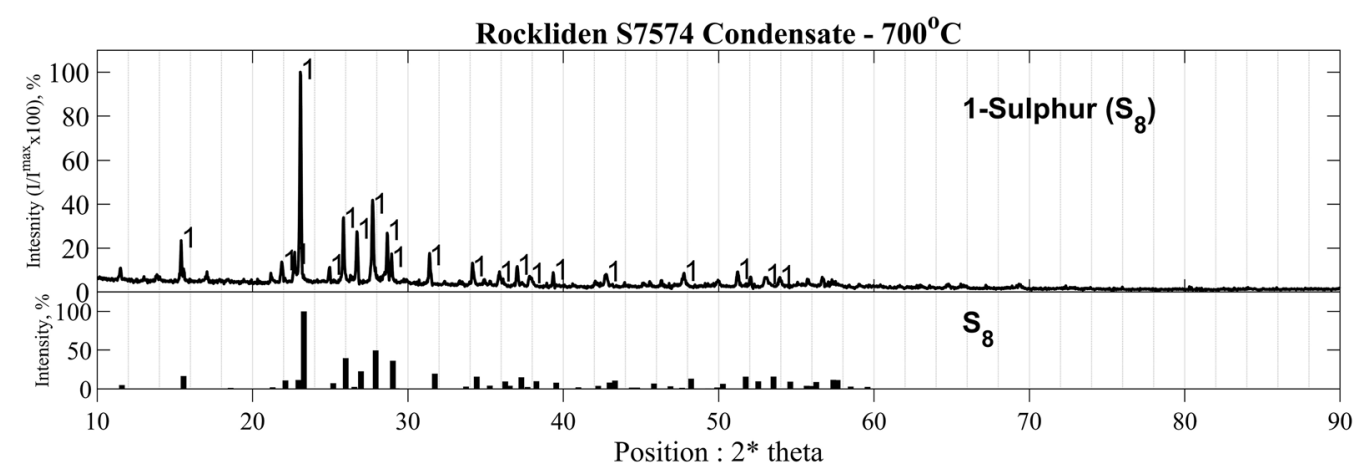

Fig. 6-XRD pattern of condensate obtained from roasting of Rockliden S7574 concentrate at $700{ }^{\circ} \mathrm{C}$ in Nitrogen atmosphere containing traces of oxygen. XRD pattern of pure cyclo-octasulfur, $\mathrm{S}_{8}(\mathrm{~s})$ from the ICSD database included for reference in the lower graph.

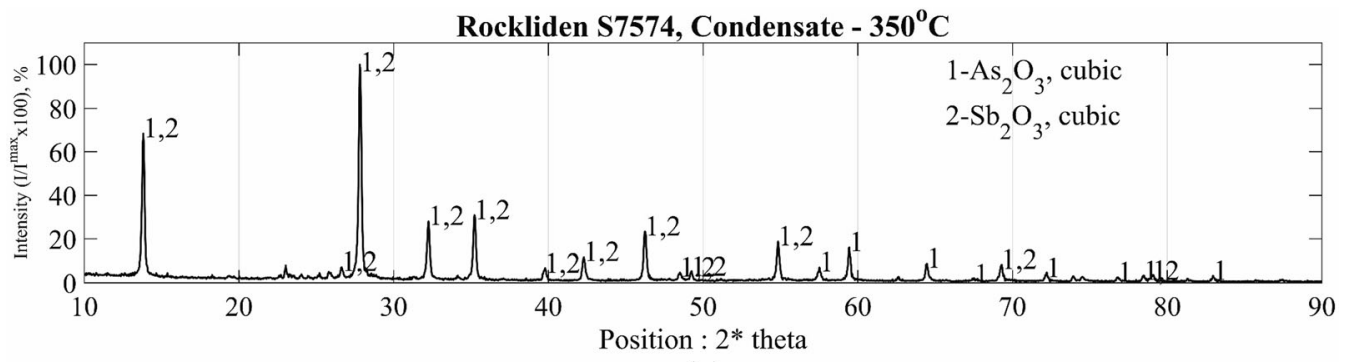

(a)

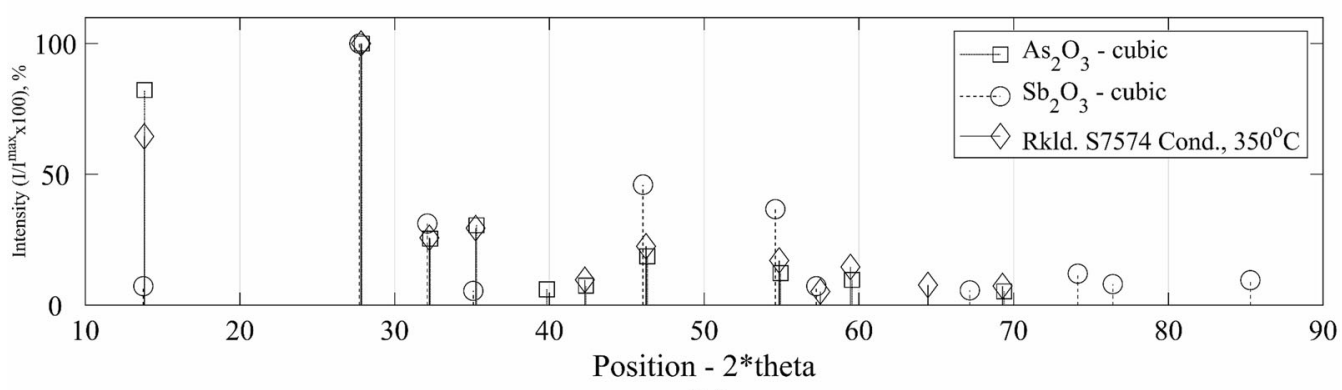

(b)

Fig. 7- (a) XRD pattern of the condensate obtained from roasting of Rockliden S7574 concentrate at $350{ }^{\circ} \mathrm{C}$ in Nitrogen atmosphere containing traces of oxygen. (b) Stem-plot showing only the peak intensities of the XRD pattern for the condensate ( $>5$ pct), along with the peak intensities of pure compounds- $\mathrm{As}_{2} \mathrm{O}_{3}$ (cubic) and $\mathrm{Sb}_{2} \mathrm{O}_{3}$ (cubic). Data of the pure compounds from ICSD database.

$(>5 \mathrm{pct})$ and reference patterns. Detailed examination of this stem-plot suggests that both in terms of peak positions and peak intensities, conformity of the measured pattern is relatively better with $\mathrm{As}_{2} \mathrm{O}_{3}$ (cubic) compared to $\mathrm{Sb}_{2} \mathrm{O}_{3}$ (cubic). The dominance of $\mathrm{As}_{2} \mathrm{O}_{3}$ (cubic) over $\mathrm{Sb}_{2} \mathrm{O}_{3}$ (cubic) in the $350{ }^{\circ} \mathrm{C}$-condensate is perplexing since the $\mathrm{Sb}$-volatilization was relatively much higher than the As-volatilization up to $400{ }^{\circ} \mathrm{C}$ in the roasting experiments, as shown in Figure 4.

To further ascertain the constituting phases, the epoxy mounts of these condensates were examined in SEM-EDS. It was found through the EDS measurements that these condensates comprised of the elements - $\mathrm{S}$, O, As and $\mathrm{Sb}$. Figure 8 presents the EDS measurements of the elemental composition of the condensates performed at numerous spots over the polished surface of the epoxy mounts. The composition values in mol pct are arranged in the decreasing order of $\mathrm{S}$-content along the $x$-axis. The nearly continuous nature of the plots, especially for the S-content in both the condensates indicates that the size of uniform phase fields in the condensate is much lower than the spot-size of EDS measurements. Otherwise, the measurement values for the elemental compositions would be clustered at the stoichiometric values corresponding to the specific compounds (for instance near $40 \mathrm{~mol}$ pct for the plot of As, if the EDS spot solely covers $\mathrm{As}_{2} \mathrm{O}_{3}$ (cubic)). Therefore, the individual compounds in these condensates are fine-grained (in sub-micron sizes) and heterogeneously intermixed, evident from wide variation in the compositions over different spots.

Following are the salient observations based on the elemental compositions in Figure 8(a) for the $700{ }^{\circ} \mathrm{C}$-condensate: 


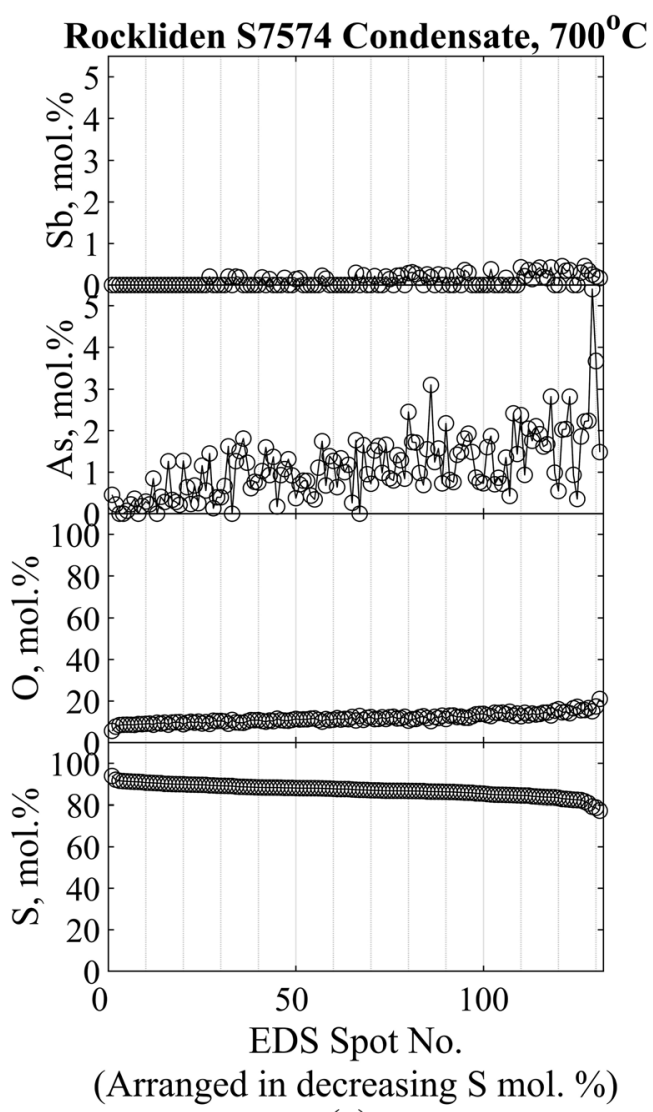

(a)

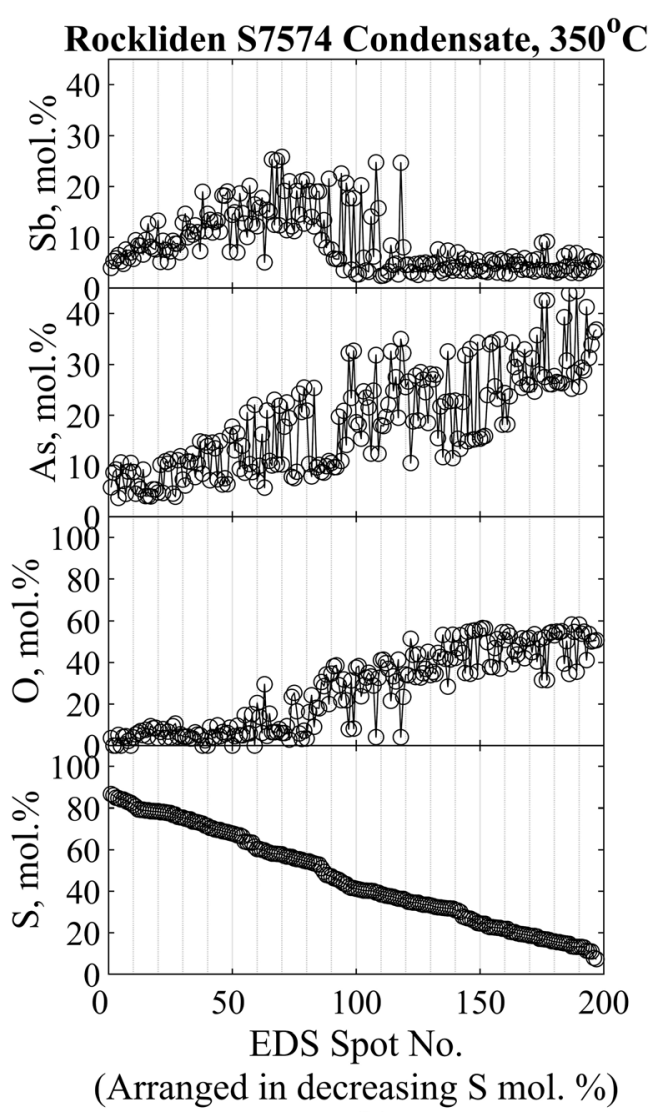

(b)

Fig. 8-EDS composition measurements at numerous spots for the condensates obtained from roasting Rockliden S7574 concentrate at (a) $700{ }^{\circ} \mathrm{C}$ (Experiment ID 700-1 in Table II), and at (b) $350{ }^{\circ} \mathrm{C}$ (Experiment ID $350-10$ in Table II). The composition values are in mol pct. along the $y$-axes. The common $x$-axis represents the spot number. These numerous EDS spots are arranged along the $x$-axis in their decreasing order of $\mathrm{S}$ mol pet content.

a. It comprises of low concentrations of $\mathrm{Sb}-$ and As-bearing phases in addition to the elemental sulfur, $\mathrm{S}_{8}(\mathrm{~s})$ suggested by the XRD pattern in Figure 6.

b. There is substantial O-content of up to approx. 20 mol pet, much higher than the As- and Sb- contents. Also, the trend of O-content and S-content are opposite. These observations point towards the existence of solid sulfur-oxide phases in the condensate (possibly in the form of polysulfur oxides and peroxides $^{[34]}$.

c. The As- and Sb-contents increase with the increasing O-content, implying that these elements exist mainly as oxides in the condensate. Based on the findings from the XRD-measurement of the $350{ }^{\circ} \mathrm{C}$-condensate in Figure 7, these oxide phases in the $700{ }^{\circ} \mathrm{C}$-condensate are likely the compounds$\mathrm{As}_{2} \mathrm{O}_{3}$ (cubic) and $\mathrm{Sb}_{2} \mathrm{O}_{3}$ (cubic).

d. The $\mathrm{Sb} / \mathrm{As}$ molar ratio is consistently very low at all the spots $(\mathrm{Sb} / \mathrm{As} \approx 0-0.2)$. However, as shown in Figure 4, the moles of $\mathrm{Sb}$ volatilized was approximately half of moles of As volatilized at $700{ }^{\circ} \mathrm{C}$. This suggests that a significant amount of the volatilized $\mathrm{Sb}$-phase could not be collected on the condensation plate. Notably, the trioxides of $\mathrm{Sb}$ and As condense at widely different temperatures. Li et al. ${ }^{[1]}$ demonstrated this in their transpiration experiments where
$\mathrm{Sb}_{2} \mathrm{O}_{3}$ (cubic) condensed at approx. $550{ }^{\circ} \mathrm{C}$ and $\mathrm{As}_{2} \mathrm{O}_{3}$ (cubic) condensed at approx. $220{ }^{\circ} \mathrm{C}$. Coming back to the present study, the condensation plate being water-cooled and located far away from the hot zone (Figure 1) would be relatively more efficient in collecting $\mathrm{As}_{2} \mathrm{O}_{3}$ (cubic) which condenses at a low temperature. Supposedly, during the roasting experiment, the $\mathrm{Sb}_{2} \mathrm{O}_{3}$ (cubic) precipitated out of the gas phase at a higher temperature as fines suspended in the carrier gas. Most of these $\mathrm{Sb}_{2} \mathrm{O}_{3}$ (cubic) fines apparently escaped from the furnace through the gas outlet (Figure 1) without depositing on the condensation plate, thereby resulting in a low $\mathrm{Sb} / \mathrm{As}$ molar ratio in the $700{ }^{\circ} \mathrm{C}$-condensate.

The prominent observations from the elemental compositions of the $350{ }^{\circ} \mathrm{C}$-condensate shown in Figure $8(\mathrm{~b})$ are as follows:

a. In addition to the oxides confirmed from the XRD-measurement in Figure 7 , the $350{ }^{\circ} \mathrm{C}$-condensate also has sulfur-bearing phases in significant proportion. This is confirmed from its wide range of S-content between 7 and 85 mol pet over different EDS spot measurements.

b. The O-content is low and nearly constant for $\mathrm{S}>50$ mol pct. In this range of $\mathrm{S}>50 \mathrm{~mol}$ pct, the $\mathrm{Sb}$ and 
As contents increase with the decreasing S-content. These trends indicate that the elements $\mathrm{Sb}$ and $\mathrm{As}$ exist in the form of sulfides at these sites of high S-content (in addition to the trioxides confirmed from the XRD-measurement in Figure 7). The Sband As-sulfides are expected to be $\mathrm{Sb}_{2} \mathrm{~S}_{3}(\mathrm{~s})$ and $\mathrm{As}_{2} \mathrm{~S}_{3}(\mathrm{~s})$ based on the findings of Komorova et al ${ }^{[35]}$ and Hague. ${ }^{[36]}$ The XRD-measurement shown in Figure 7 could not detect $\mathrm{Sb}_{2} \mathrm{~S}_{3}(\mathrm{~s})$ and $\mathrm{As}_{2} \mathrm{~S}_{3}(\mathrm{~s})$ in the $350{ }^{\circ} \mathrm{C}$-condensate as these two compounds generally condense into their amorphous solid forms. ${ }^{\text {[37,38] }}$

c. For $\mathrm{S}<50 \mathrm{~mol}$ pct, O-content starts to increase, which is accompanied by a persistent increase in As-content, but there is a sudden drop in Sb-content to a low and nearly constant value. This behavior of low $\mathrm{Sb} / \mathrm{As}$ molar ratio at significant levels of O-content $(\mathrm{O}>10 \mathrm{~mol} \mathrm{pct})$ is common in both the $350{ }^{\circ} \mathrm{C}$-condensate and the $700{ }^{\circ} \mathrm{C}$-condensate. The more prominent drop of $\mathrm{Sb} / \mathrm{As}$ molar ratio with increase in O-content in the $350{ }^{\circ} \mathrm{C}$-condensate can again be attributed to the inefficient collection of $\mathrm{Sb}_{2} \mathrm{O}_{3}(\mathrm{~s})$ over the condensation plate (owing to the condensation of $\mathrm{Sb}_{2} \mathrm{O}_{3}(\mathrm{~s})$ starting from approx. $\left.550{ }^{\circ} \mathrm{C}^{[1]}\right)$.

Figure 9 presents the same compositional data for the $350{ }^{\circ} \mathrm{C}$-condensate of Figure $8(\mathrm{~b})$, but in the form of a scatter plot between $\mathrm{O}$ mol pct vs. $\mathrm{S}$ mol pct. EDS measurements on a hypothetical mixture containing finely intermixed $\mathrm{As}_{2} \mathrm{~S}_{3}(\mathrm{~s}), \mathrm{Sb}_{2} \mathrm{~S}_{3}(\mathrm{~s}), \mathrm{As}_{2} \mathrm{O}_{3}$ (cubic), $\mathrm{Sb}_{2} \mathrm{O}_{3}$ (cubic) would follow the line $\mathrm{AB}$ shown in this plot. The actual measurements follow this line as a lower limit of S-content. The measured data points above this line indicate that the spots contain elemental sulfur in addition to the trisulfides and trioxides of $\mathrm{Sb}$ and $\mathrm{As}$. The upper limits of S-content also nearly fit over a straight line CD, almost parallel to the line AB. This line having a slope of -1 , suggests that the elemental sulfur, $\mathrm{S}_{n}(\mathrm{~s})$ got partially oxidized to form polysulfur oxides, $\mathrm{S}_{n-x} \mathrm{O}_{x}(\mathrm{~s})$ via an equal replacement of $\mathrm{S}$ atoms by $\mathrm{O}$

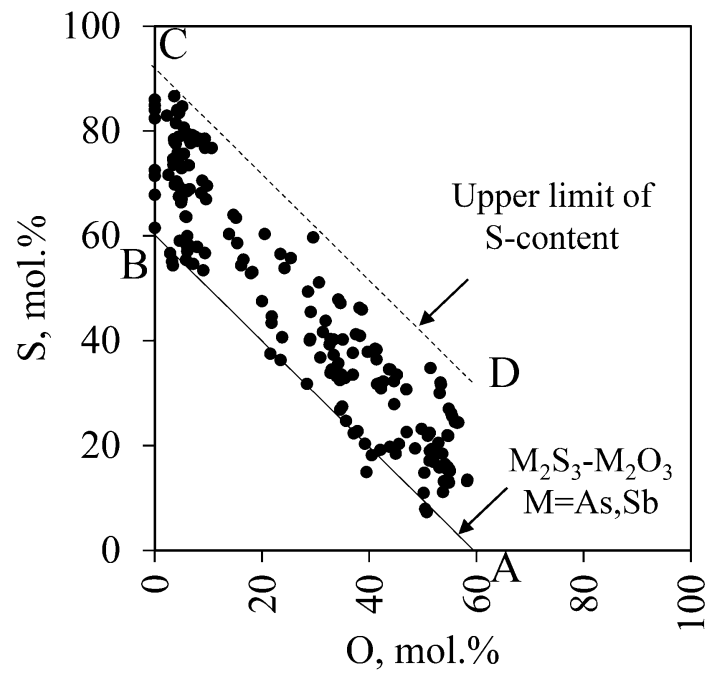

Fig. 9-Plot of S-content vs. O-content from EDS composition measurements at numerous spots for the $350{ }^{\circ} \mathrm{C}$-condensate. atoms ( $x$-moles). Equal replacement of $\mathrm{S}$ by $\mathrm{O}$ means that, for instance, if the unoxidized elemental sulfur in the condensate was $\mathrm{S}_{8}(\mathrm{~s})$, the polysulfur oxide compounds would be $\mathrm{S}_{7} \mathrm{O}(\mathrm{s}), \mathrm{S}_{6} \mathrm{O}_{2}(\mathrm{~s})$ etc., and not $\mathrm{S}_{8} \mathrm{O}(\mathrm{s})$, $\mathrm{S}_{7} \mathrm{O}_{2}(\mathrm{~s})$ or $\mathrm{S}_{6} \mathrm{O}(\mathrm{s})$. Also, the $\mathrm{S}$-content at $\mathrm{O}=0 \mathrm{~mol}$ pet not reaching 100 mol pet yet again indicates that the elemental sulfur is fine-sized and much smaller than the spot-size of EDS measurements, such that no spot comprises of only the elemental sulfur.

Based on the above characterization investigations, the condensates collected at room temperature in this study during the roasting of Rockliden S7574 concentrate in Nitrogen atmosphere (bearing traces of oxygen) were found to consist of the following compounds:

1. Elemental sulfur, $\mathrm{S}_{n}(\mathrm{~s})$ and solid sulfur-oxides, $\mathrm{S}_{n-x} \mathrm{O}_{x}(\mathrm{~s})$;

2. Trioxides of $\mathrm{Sb}$ and $\mathrm{As}-\mathrm{Sb}_{2} \mathrm{O}_{3}$ (cubic), $\mathrm{As}_{2} \mathrm{O}_{3}$ (cubic);

3. Trisulfides of $\mathrm{Sb}$ and $\mathrm{As}-\mathrm{Sb}_{2} \mathrm{~S}_{3}(\mathrm{~s}), \mathrm{As}_{2} \mathrm{~S}_{3}(\mathrm{~s})$

\section{Evaluation of Mineral Transformations Leading to $\mathrm{Sb}$ - and As-Volatilization at $350{ }^{\circ} \mathrm{C}$}

The Rockliden S7574 concentrate exhibited higher Sb-volatilization compared to As-volatilization below $500{ }^{\circ} \mathrm{C}$ in Nitrogen atmosphere, as presented in Figure 4. Arsenopyrite is the only As-bearing mineral in this concentrate. $^{[24]}$ Figure 10 presents a BSE image of a fully liberated particle of arsenopyrite in the calcine obtained from the Experiment ID 350-10 (Table II). The BSE gray-level throughout the particle is uniform, suggesting lack of any perceptible transformationin arsenopyrite at $350{ }^{\circ} \mathrm{C}$. The elemental compositions at the indicated spots in this figure measured via EDS are presented in Table V. As content was found to be slightly lesser than in the theoretical stoichiometry of

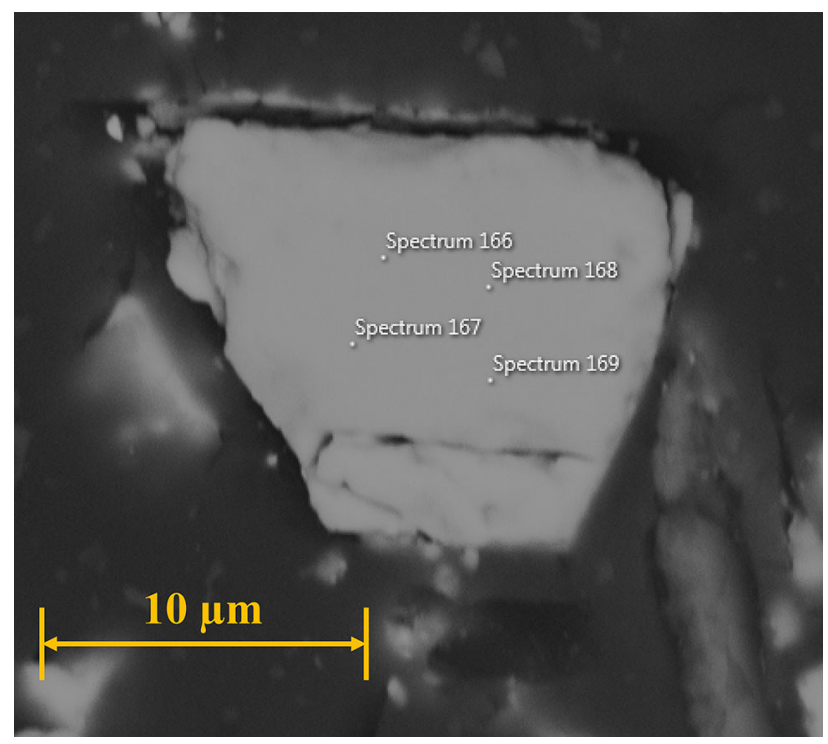

Fig. 10-BSE image of a fully liberated particle of arsenopyrite in the calcine obtained from roasting Rockliden S7574 concentrate in Nitrogen atmosphere (containing traces of oxygen) at $350{ }^{\circ} \mathrm{C}$ via Experiment ID 350-10 (Table II). Sites of EDS spot measurements also indicated. 
arsenopyrite (33.3 mol pct Fe, 33.3 mol pct As, 33.3 mol pct S). Therefore, arsenopyrite experienced only minor transformation at $350{ }^{\circ} \mathrm{C}$, consequent to which the As-volatilization was low below $500{ }^{\circ} \mathrm{C}$ (Figure 4).

Regarding substantial Sb-volatilization at low temperatures, Prasad et al. ${ }^{[24]}$ in a previous study attributed this behavior to the thermal decomposition of gudmundite (FeSbS) into pyrrhotite and metallic-Sb between $300{ }^{\circ} \mathrm{C}$ and $400{ }^{\circ} \mathrm{C}$. They also demonstrated that other Sb-bearing minerals in the concentrate did not experience any noticeable transformation at $350{ }^{\circ} \mathrm{C}$,

Table V. Elemental Composition Obtained from EDS Spot Measurements at Sites Indicated in Fig. 10 for the Mineral Arsenopyrite in the Calcine from Experiment ID 350-10

\begin{tabular}{lccc}
\hline Spot Number & Fe, mol pct & As, mol pct & S, mol pct \\
\hline Spectrum 166 & 33.8 & 31.3 & 34.9 \\
Spectrum 167 & 33.3 & 31.6 & 35.1 \\
Spectrum 168 & 33.7 & 31.7 & 34.6 \\
Spectrum 169 & 33.0 & 32.3 & 34.7 \\
\hline
\end{tabular}

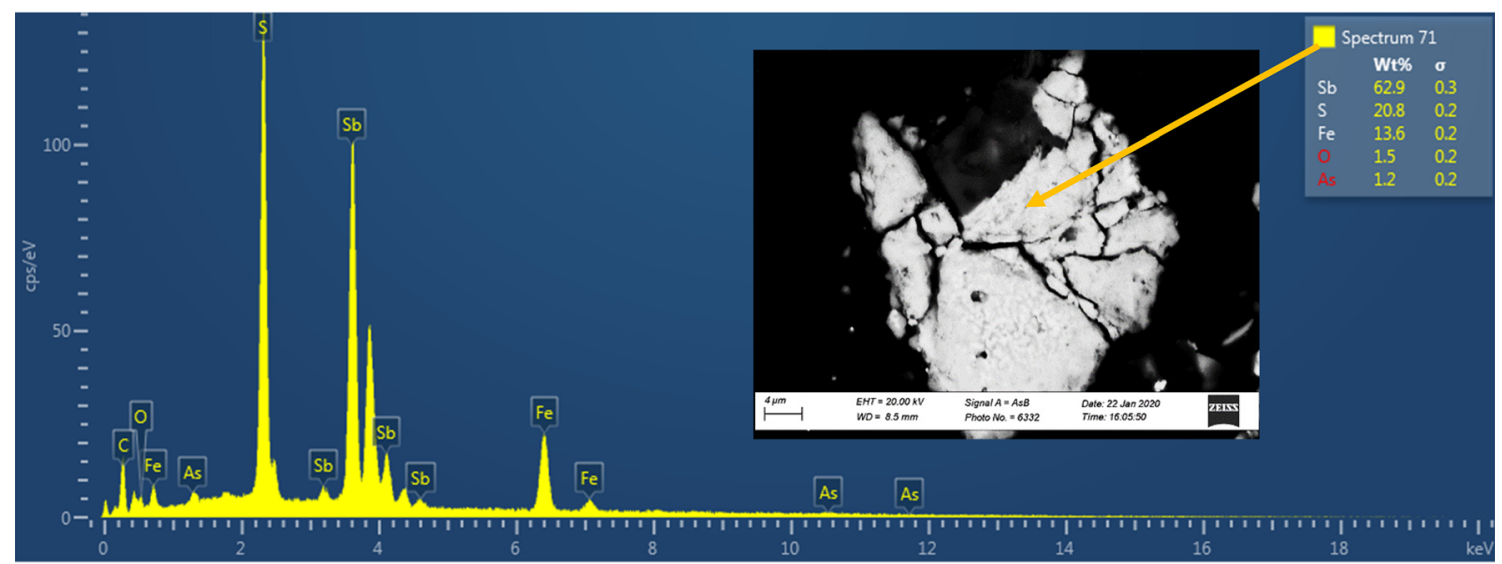

(a)

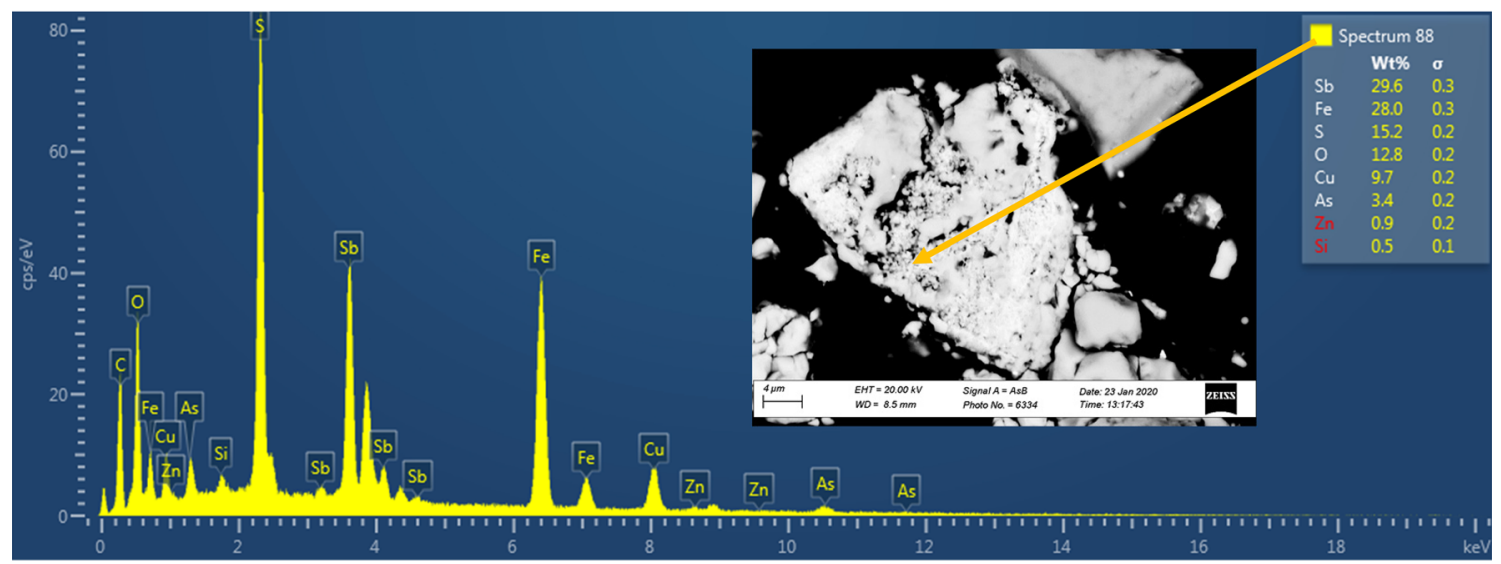

(b)

Fig. 11-EDS spectra for the composition measurement showing minor concentration of Arsenic at the sites of originally gudmundite (partially transformed) in the calcine obtained from roasting Rockliden S7574 concentrate at $350{ }^{\circ} \mathrm{C}$ (Experiment ID 350 - 10 in Table II) (a) in a fully liberated gudmundite particle and $(b)$ in a particle hosting complex intergrowth of gudmundite and chalcopyrite. 
As-bearing species in the gas phase with the metallic-Sb generated from the thermal decomposition of gudmundite. ${ }^{[24]}$ This observation is in line with the earlier evidences of formation of complex Sb-As compounds during volatilization when $\mathrm{Sb}$ and As coexist in the material undergoing roasting. ${ }^{[1-3,9,10,15]}$

\section{THERMODYNAMIC STUDY}

The Sb- and As-bearing volatilized species could not be consistently detected in the gas phase by QMS due to their low concentrations. Consequently, a thermodynamic calculation was performed for estimation of their quantities produced during the Experiment ID 350-10 (Table II). This was done in a thermochemical software FactSage $7.3,{ }^{[39]}$ using its 'Equilib' module and the FactPS database of pure substances. An important objective of this thermodynamic calculation was to compare the theoretical equilibrium concentrations of As- and Sb-bearing oxides and sulfides generated during roasting at $350{ }^{\circ} \mathrm{C}$. Additionally, the intention was to investigate the possibility of formation of the Sb-As complex gaseous species. The data for the three known complex oxide compounds- $\mathrm{As}_{n} \mathrm{Sb}_{4-n} \mathrm{O}_{6}(\mathrm{~g})(n=1,2$, 3 ), are available in the FactPS database. However, this database does not consist of the data for complex sulfide compounds $\mathrm{As}_{n} \mathrm{Sb}_{4-n} \mathrm{~S}_{6}(\mathrm{~g})(n=1,2,3)$. Among these three complex sulfides, thermodynamic data are available in the literature only for $\mathrm{AsSb}_{3} \mathrm{~S}_{6}(\mathrm{~g})$ (Westphal ${ }^{[11]}$ and HSC Chemistry ${ }^{[40]}$ ). Consequently, $\mathrm{AsSb}_{3} \mathrm{~S}_{6}(\mathrm{~g})$ was included in the equilibrium calculation in FactSage by replicating its data from HSC chemistry. (Data of $\mathrm{AsSb}_{3} \mathrm{~S}_{6}(\mathrm{~g})$ taken from HSC Chemistry into FactSage is presented in Appendix 1, Table A1.1).

\section{A. Definition of Thermodynamic System and Initial Conditions}

The calculations were primarily based on the findings from Prasad et al. ${ }^{[24]}$ that Sb-volatilization at $350{ }^{\circ} \mathrm{C}$ occurred through the thermal decomposition of gudmundite (FeSbS) into pyrrhotite $\left(\mathrm{Fe}_{1-x} \mathrm{~S}\right)$ and metallic-Sb. The thermodynamic framework, therefore, involved a set of simplified initial conditions of $\mathrm{Sb}(\mathrm{s})$ interacting with $\mathrm{N}_{2}(\mathrm{~g}), \mathrm{O}_{2}(\mathrm{~g}), \mathrm{H}_{2} \mathrm{O}(\mathrm{g})$ (components of the carrier gas), and $\mathrm{S}_{2}(\mathrm{~g})$ (labile sulfur volatilized from the concentrate) at $350^{\circ} \mathrm{C}$. An As-bearing sulfide vapor phase $\mathrm{As}_{4} \mathrm{~S}_{4}(\mathrm{~g})$ was also included for consideration in the gas mixture. This was based on the detection of As at the sites of the transformed gudmundite, presented in Figure 11. The quantity of $\mathrm{As}_{4} \mathrm{~S}_{4}(\mathrm{~g})$ was set as a study parameter and varied in a range of relatively insignificant values compared to the other gaseous components. The small quantities of $\mathrm{As}_{4} \mathrm{~S}_{4}(\mathrm{~g})$ in the gas mixture were considered based on the observation of imperceptible transformation in the As-bearing mineral, arsenopyrite, at $350{ }^{\circ} \mathrm{C}$ (Figure 10, Table V). The model inputs of initial quantities of the reactants were calculated on the basis of 1 mole of $\mathrm{Sb}(\mathrm{s})$. Determination of the quantities of the gaseous compounds commensurate with 1 mole of $\mathrm{Sb}(\mathrm{s})$ is presented in Appendix 1, Table A1.2.

\section{B. Results of the Thermodynamic Calculations and Discussion}

Figure 12 presents the quantities of Sb- and As-bearing oxide and sulfide gaseous species (with available thermodynamic data) equilibrating at $350{ }^{\circ} \mathrm{C}$ corresponding to different initial quantities of As-sulfide in the gas phase.

The results suggest that the concentration of individual oxide and sulfide compounds of $\mathrm{As}$ and $\mathrm{Sb}$ will be much higher than those of the complex heteronuclear $\mathrm{Sb}$-As compounds- $\mathrm{As}_{n} \mathrm{Sb}_{4-n} \mathrm{O}_{6}(\mathrm{~g})$ and $\mathrm{As}_{n} \mathrm{Sb}_{4-n} \mathrm{~S}_{6}(\mathrm{~g})$. However, the equilibrium calculation does not include the compounds- $\mathrm{As}_{3} \mathrm{SbS}_{6}(\mathrm{~g})$ and $\mathrm{As}_{2} \mathrm{Sb}_{2} \mathrm{~S}_{6}(\mathrm{~g})$ due to unavailability of their thermodynamic data. These two compounds are expected to be present in much higher concentration than $\mathrm{AsSb}_{3} \mathrm{~S}_{6}(\mathrm{~g})$ at lower temperatures, for instance at $300{ }^{\circ} \mathrm{C}$ as measured by Mauser. ${ }^{[2]}$ Therefore, the vapor-phase complexation of sulfides of $\mathrm{Sb}$ and As might be prominent in reality, contrary to the indications from thermodynamic calculation.

Secondly, in Figure 12, the concentration of all the three heteronuclear oxide compounds- $\mathrm{As}_{3} \mathrm{SbO}_{6}(\mathrm{~g})$, $\mathrm{As}_{2} \mathrm{Sb}_{2} \mathrm{O}_{6}(\mathrm{~g})$, and $\mathrm{AsSb}_{3} \mathrm{O}_{6}(\mathrm{~g})$, are much lower than for the complex sulfide- $\mathrm{AsSb}_{3} \mathrm{~S}_{6}(\mathrm{~g})$. Therefore, the $\mathrm{Sb}$-As complex oxides are likely to be relatively insignificant in the gas phase compared to the $\mathrm{Sb}-\mathrm{As}$ complex sulfides

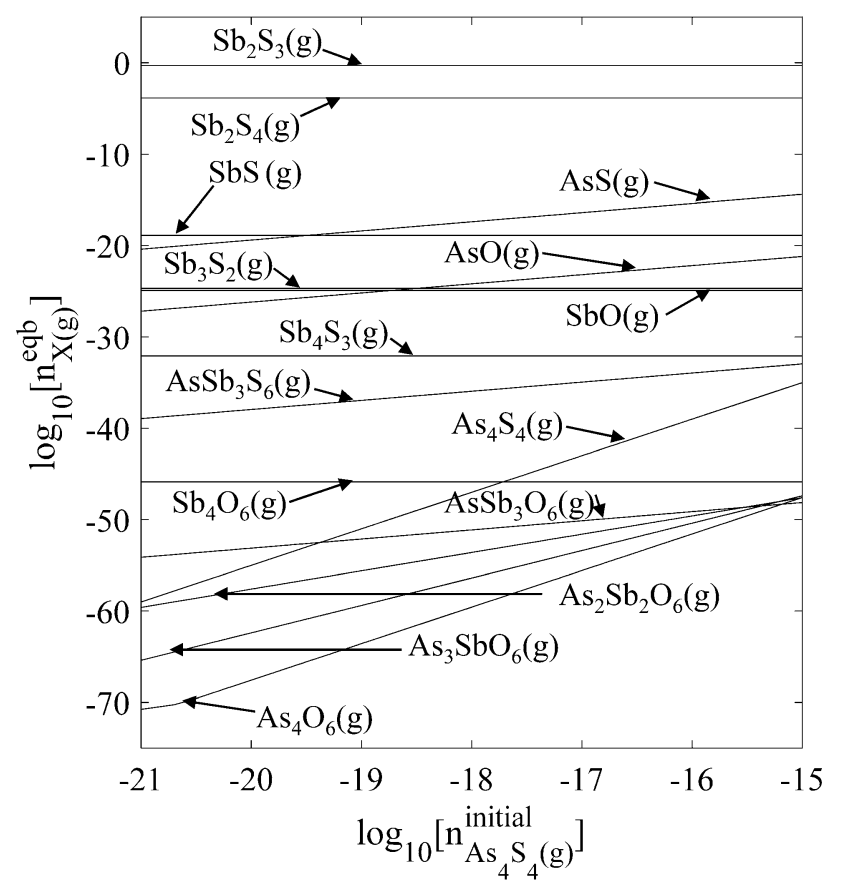

Fig. 12-Equilibrium quantities of gaseous oxide and sulfide compounds of $\mathrm{Sb}$ and $\mathrm{As}$ at $350^{\circ} \mathrm{C}$. Initial condition prior to equilibrium is 1 mole of $\mathrm{Sb}(\mathrm{s})$ together with a gas phase consisting of $\mathrm{N}_{2}(\mathrm{~g}), \mathrm{O}_{2}(\mathrm{~g}), \mathrm{H}_{2} \mathrm{O}(\mathrm{g}), \mathrm{S}_{2}(\mathrm{~g})$, and $\mathrm{As}_{4} \mathrm{~S}_{4}(\mathrm{~g})$ in quantities listed in Appendix 1, Table A1.2. 


\section{MODELING OF CONDENSATE COMPOSITIONAL DOMAINS}

Phase quantification through direct measurements like QEMSCAN could not be possible for these condensates due to the small size of uniform phase fields, and the extensive heterogeneity in compositions over different spots (Figure 8). With focus on the $350{ }^{\circ} \mathrm{C}$-condensate comprising substantial $\mathrm{Sb}$ - and As-bearing phases, an approach of partial quantification of solid phases in the condensate aided by a stochastic modeling approach is hereby presented.

The stochastic model calculates the elemental composition of the condensate by assuming random proportion of the identified solid phases- $\mathrm{As}_{2} \mathrm{~S}_{3}(\mathrm{~s})$, $\mathrm{Sb}_{2} \mathrm{~S}_{3}(\mathrm{~s}), \mathrm{As}_{2} \mathrm{O}_{3}(\mathrm{~s}), \mathrm{Sb}_{2} \mathrm{O}_{3}(\mathrm{~s}), \mathrm{S}_{n}(\mathrm{~s})$, and $\mathrm{S}_{n-x} \mathrm{O}_{x}(\mathrm{~s})$. Proportions of these solid phases in the condensate are assigned using random numbers between 0 and 1 . The chemical stoichiometry of these individual solid phases are used subsequently to arrive at the elemental composition of the condensate in $\mathrm{S}, \mathrm{O}, \mathrm{As}$, and $\mathrm{Sb}$ mol pct. A composition calculated by the model, therefore, tends to simulate the EDS measurement at a spot with non-uniform phase field, comprising varying proportions of the finely intermixed solid phases (in sub-micronic sizes, presented in Section IV-B).

The model is run multiple times with the same set of inputs (explanation of the model inputs forthcoming) to generate several distinct sets of random elemental composition. Since the condensate comprises of the four elements- $\mathrm{S}, \mathrm{O}, \mathrm{As}$, and $\mathrm{Sb}$, its composition can be plotted in six different binary scatter plots $\left({ }^{4} \mathrm{C}_{2}=6\right)$. Therefore, the scatter plots $-\mathrm{S} v s . \mathrm{O}, \mathrm{S} v s . \mathrm{As}, \mathrm{S} v s . \mathrm{Sb}$, $\mathrm{O}$ vs. As, $\mathrm{O}$ vs. $\mathrm{Sb}$, and $\mathrm{As}$ vs. $\mathrm{Sb}$ are generated, and compositional limits/domains are obtained by bounding the plotted compositions. A compositional limit in $\mathrm{S}$ vs. O plot obtained by running the model with a specific set of input parameters is illustrated in Figure 13.

\section{A. Model Input Parameters}

The input parameters of the stochastic model are explained below:

1. $\left(\frac{\mathrm{Sb}_{2} \mathrm{~S}_{3}(\mathrm{~s})}{\mathrm{Sb}_{2} \mathrm{~S}_{3}(\mathrm{~s})+\mathrm{As}_{2} \mathrm{~S}_{3}(\mathrm{~s})}\right)$ : Formation of the condensate took place through the condensation of volatiles produced during roasting. Therefore, the elemental composition of the condensate could show some correlations with the stoichiometry of the As- and Sb-bearing compounds in the gas phase. The thermodynamic analysis in Section V suggested that the Sb-As complex oxides, $\mathrm{As}_{n} \mathrm{Sb}_{4-n} \mathrm{O}_{6}(\mathrm{~g})$ would be negligible during roasting. However, due to the unavailability of thermodynamic data for $\mathrm{As}_{3} \mathrm{SbS}_{6}(\mathrm{~g})$ and $\mathrm{As}_{2} \mathrm{Sb}_{2} \mathrm{~S}_{6}(\mathrm{~g})$, the significance of the complex gaseous sulfides, $\mathrm{As}_{n} \mathrm{Sb}_{4-n} \mathrm{~S}_{6}(\mathrm{~g})$ could not be thermodynamically assessed. The stochastic model tests the possibility of $\mathrm{Sb}_{2} \mathrm{~S}_{3}$ (s) and $\mathrm{As}_{2} \mathrm{~S}_{3}$ (s) in the condensate to originate from the below condensation reaction, Eq. [1]:

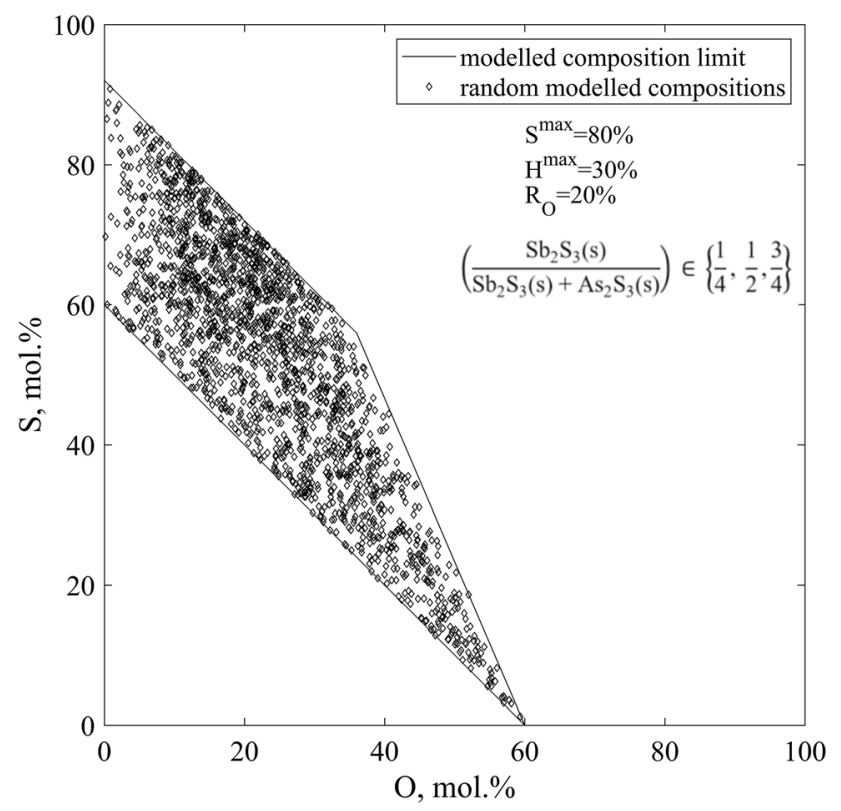

Fig. 13-An illustration of compositional domains/limits obtained from repeated runs of the stochastic model generating elemental composition of the $350{ }^{\circ} \mathrm{C}$-condensate.

$$
\begin{aligned}
2 \mathrm{As}_{n} \mathrm{Sb}_{4-n} \mathrm{~S}_{6}(\mathrm{~g}) & \rightarrow n \mathrm{As}_{2} \mathrm{~S}_{3}(\mathrm{~s})+(4-n) \mathrm{Sb}_{2} \mathrm{~S}_{3}(\mathrm{~s}) ; n \\
& =1,2,3
\end{aligned}
$$

The model runs in two different modes as described in Table VI. When Mode $=1$, it is considered that $\mathrm{As}_{2} \mathrm{~S}_{3}(\mathrm{~s})$ and $\mathrm{Sb}_{2} \mathrm{~S}_{3}(\mathrm{~s})$ in the condensate originated from the condensation of only the complex gaseous sulfide compounds- $\mathrm{As}_{3} \mathrm{SbS}_{6}(\mathrm{~g}), \mathrm{As}_{2} \mathrm{Sb}_{2} \mathrm{~S}_{6}(\mathrm{~g})$, and $\mathrm{AsSb}_{3} \mathrm{~S}_{6}(\mathrm{~g})$, in accordance with Eq. [1]. Consequently, the molar proportion of the trisulfides in the condensate, $\left(\frac{\mathrm{Sb}_{2} \mathrm{~S}_{3}(\mathrm{~s})}{\mathrm{Sb}_{2} \mathrm{~S}_{3}(s)+\mathrm{As}_{2} \mathrm{~S}_{3}(\mathrm{~s})}\right)$ at any site will be a particular value $\epsilon\left\{\frac{1}{4}, \frac{1}{2}, \frac{3}{4}\right\}$ (as $n \in\{1,2,3\}$ in Eq. [1]). A value from this set is selected randomly by the model in each run as presented in Table VI. Else, Mode $=2$ considers the molar proportion of the trisulfides in the condensate to be a random value between 0 to 1 , which would mean insignificance of the complex sulfide vapors $\mathrm{As}_{n} \mathrm{Sb}_{4-n} \mathrm{~S}_{6}(\mathrm{~g})$ in the gas phase.

2. $R_{\mathrm{O}}=100 \times\left(\frac{\mathrm{Sb}_{2} \mathrm{O}_{3}(\mathrm{~s})}{\mathrm{Sb}_{2} \mathrm{O}_{3}(\mathrm{~s})+\mathrm{As}_{2} \mathrm{O}_{3}(\mathrm{~s})}\right), R_{\mathrm{O}} \in[0,100]$ :

EDS measurements over the $350{ }^{\circ} \mathrm{C}$-condensate in Figure 8(b) suggested a reasonably limited deposition of $\mathrm{Sb}_{2} \mathrm{O}_{3}(\mathrm{~s})$ on the condensation plate compared to $\mathrm{As}_{2} \mathrm{O}_{3}(\mathrm{~s})$. The model incorporates this effect through an input parameter, $R_{\mathrm{O}} \epsilon[0,100]$, signifying the relative inefficiency of the condensation plate in collecting $\mathrm{Sb}_{2} \mathrm{O}_{3}(\mathrm{~s})$ compared to $\mathrm{As}_{2} \mathrm{O}_{3}(\mathrm{~s})$. Molar ratio of the solid trioxides of $\mathrm{Sb}$ and $\mathrm{As}$ in the condensate would, therefore, be related to $R_{\mathrm{O}}$ as per equation below: 
Table VI. Description of 'Mode' as an Input to the Stochastic Model for Condensate Composition

\begin{tabular}{|c|c|c|c|}
\hline Mode & Molar Propor & ion & Mode Description \\
\hline 1 & $\left(\frac{\mathrm{Sb}_{2} \mathrm{~S}_{3}(\mathrm{~s})}{\mathrm{Sb}_{2} \mathrm{~S}_{3}(\mathrm{~s})+\mathrm{As}_{2} \mathrm{~S}_{3}(\mathrm{~s})}\right)$ & $\in\left\{\frac{1}{4}, \frac{1}{2}, \frac{3}{4}\right\}$ & $\begin{array}{c}\mathrm{As}_{2} \mathrm{~S}_{3}(\mathrm{~s}) \text { and } \mathrm{Sb}_{2} \mathrm{~S}_{3}(\mathrm{~s}) \text { in the condensate produced predominently from } \\
\text { the condensation of } \mathrm{As}_{4-n} \mathrm{Sb}_{n} \mathrm{~S}_{6}(\mathrm{~g}), n=1,2,3\end{array}$ \\
\hline 2 & $\left(\frac{\mathrm{Sb}_{2} \mathrm{~S}_{3}(\mathrm{~s})}{\mathrm{Sb}_{2} \mathrm{~S}_{3}(\mathrm{~s})+\mathrm{As}_{2} \mathrm{~S}_{3}(\mathrm{~s})}\right)$ & $\in[0,1]$ & $\begin{array}{l}\mathrm{As}_{2} \mathrm{~S}_{3}(\mathrm{~s}) \text { and } \mathrm{Sb}_{2} \mathrm{~S}_{3}(\mathrm{~s}) \text { in the condensate produced predominently from the } \\
\text { condensation of phases other than } \mathrm{As}_{4-n} \mathrm{Sb}_{n} \mathrm{~S}_{6}(\mathrm{~g}), n=1,2,3\end{array}$ \\
\hline
\end{tabular}

$$
\frac{\mathrm{Sb}_{2} \mathrm{O}_{3}(\mathrm{~s})}{\mathrm{As}_{2} \mathrm{O}_{3}(\mathrm{~s})}=\left(\frac{100}{R_{\mathrm{O}}}-1\right)^{-1}
$$

3. $S^{\max }$ : The condensate consists of sulfur in the form of $\mathrm{S}_{n}(\mathrm{~s})$ and $\mathrm{S}_{n-x} \mathrm{O}_{x}(\mathrm{~s})$, in addition to the sulfur in $\mathrm{As}_{2} \mathrm{~S}_{3}(\mathrm{~s})$ and $\mathrm{Sb}_{2} \mathrm{~S}_{3}(\mathrm{~s})$. $S^{\max }$ represents the maximum value of this extra sulfur content which can be found at any spot in the extensively heterogeneous condensate.

4. $H^{\text {max}}$ : Regarding the polysulfur oxides, $\mathrm{S}_{n-x} \mathrm{O}_{x}(\mathrm{~s})$ in the condensate, it is assumed that they were produced by the partial oxidation of condensed elemental sulfur, $\mathrm{S}_{n}(\mathrm{~s})$ via Reaction [3], and not by the oxidation of gaseous elemental sulfur $\mathrm{S}_{2}(\mathrm{~g})$.

$$
\mathrm{S}_{n}(\mathrm{~s})+\frac{3 x}{2} \mathrm{O}_{2}(\mathrm{~g}) \rightarrow \mathrm{S}_{n-x} \mathrm{O}_{x}(\mathrm{~s})+x \mathrm{SO}_{2}(\mathrm{~g})
$$

Evidently, in the above reaction, it is also presumed that there is an equal replacement of $\mathrm{S}$ atoms by $\mathrm{O}$ atoms ( $x$-moles) in $\mathrm{S}_{n}(\mathrm{~s})$ to form solid sulfur oxides, $\mathrm{S}_{n} \mathrm{O}_{n-x}(\mathrm{~s})$. This is based on the slope of -1 for the line $C D$ representing sulfur upper limit in the O-vs.-S plot in Figure 9. $H^{\max }$ signifies the oxygen content (mol pct) in the most oxidized polysulfur oxide phase in the heterogenous condensate. Oxygen content in $\mathrm{S}_{n-x} \mathrm{O}_{x}(\mathrm{~s})$ is expressed as $\mathrm{H}$, described in the below Eq. [4].

$$
H=\left(\frac{x}{n} \times 100\right), H \in\left[0 H^{\max }\right]
$$

For instance, if the condensate comprises of all of these polysulfur oxides $-\mathrm{S}_{7} \mathrm{O}(\mathrm{s}), \mathrm{S}_{6} \mathrm{O}_{2}(\mathrm{~s}), \mathrm{S}_{5} \mathrm{O}_{3}(\mathrm{~s})$, and $\mathrm{S}_{4} \mathrm{O}_{4}(\mathrm{~s})$ obtained from differing extents of oxidation of $\mathrm{S}_{8}(\mathrm{~s}), H^{\mathrm{max}}$ should be equal to $50 \mathrm{~mol}$ pct, corresponding to the oxygen content in the most oxidized compound $\mathrm{S}_{4} \mathrm{O}_{4}(\mathrm{~s})$.

5. $\mathrm{N}^{\text {random }}=$ Number of times the model is run repeatedly, generating a set of random elemental composition of the condensate: $\left\{\mathrm{X}_{\mathrm{i}}, i \in \mathrm{As}, \mathrm{Sb}, \mathrm{S}, \mathrm{O}\right\}$ in mol pct after each run. These composition values satisfy the below condition in Eq. [5].

$$
\sum_{\mathrm{i}=\mathrm{As}, \mathrm{Sb}, \mathrm{S}, \mathrm{O}} \mathrm{X}_{\mathrm{i}}=100 \mathrm{pct}
$$

A detailed description of the mathematical formulation of the stochastic model is presented in Appendix 2.

\section{B. Parametric Study}

Appropriate values of the input parameters $-S^{\max }$, $H^{\max }$, Mode, and $R_{\mathrm{O}}$ are obtained by performing parametric analyses of the model and comparing the results with the EDS measurements of elemental composition for the $350{ }^{\circ} \mathrm{C}$-condensate (already presented in Figures 8(b) and 9).

Figure 14 presents the parametric study results obtained by changing the values of $H^{\max }$ and $S^{\max }$ in succession. The compositional limits in a $\mathrm{S} v s$. O plot form domain boundaries in the shape of trapezium. Figure 14(a) shows that the value of $H^{\max }$ decides the orientation of the line AD, one of the non-parallel sides in this trapezium (Lines $\mathrm{AD}_{1}$ to $\mathrm{AD}_{6}$ corresponding to increasing values of $H^{\max }$ from 0 to 100 mol. pct). Superimposition of the EDS measurements suggests that the appropriate value of $H^{\max }$ is $60 \mathrm{~mol} \mathrm{pct}$, corresponding to the line $\mathrm{AD}_{4}$, which offers the closest confinement of the data points from EDS measurements. Therefore, the most oxidized polysulfur oxide in the condensate should be approximately $\mathrm{S}_{3} \mathrm{O}_{5}(\mathrm{~s})$, owing to $x \approx 5$ in the chemical formula, $\mathrm{S}_{n-x} \mathrm{O}_{x}(\mathrm{~s})$ (rounded off from the exact value of $x=4.8$, calculated by substituting $H=H^{\max }=60$ mol pct and $n=8$ corresponding to cyclo-octasulfur in Eq. [4]). Similarly, as shown in Figure 14(b), the location of the line CD is decided by the value of $S^{\max }$ and $S^{\max }=75 \mathrm{~mol}$ pct leads to an apt validation with the EDS measurements. Consequently, the sulfur content representing elemental sulfur, $\mathrm{S}_{n}(\mathrm{~s})$ (excluding sulfur in the As, Sb trisulfides), is below $75 \mathrm{~mol}$ pct at any site in the condensate.

After determining the suitable values of $H^{\max }$ and $S^{\max }$, subsequently, the model is tested with changing input values of Mode and $R_{\mathrm{O}}$. The effect of these changes are studied in the As vs. Sb plot owing to the higher relevance of Mode and $R_{\mathrm{O}}$ in the modeled $\mathrm{Sb}$ and As-contents. Figure 15(a) shows that changing the value of $R_{\mathrm{O}}$ has no effect on the As-Sb compositional domain when $\quad$ Mode $=2 \quad$ (Table VI, $\left.\left(\frac{\mathrm{Sb}_{2} \mathrm{~S}_{3}(\mathrm{~s})}{\mathrm{Sb}_{2} \mathrm{~S}_{3}(\mathrm{~s})+\mathrm{As}_{2} \mathrm{~S}_{3}(\mathrm{~s})}\right) \in[0,1]\right)$. The same domain 


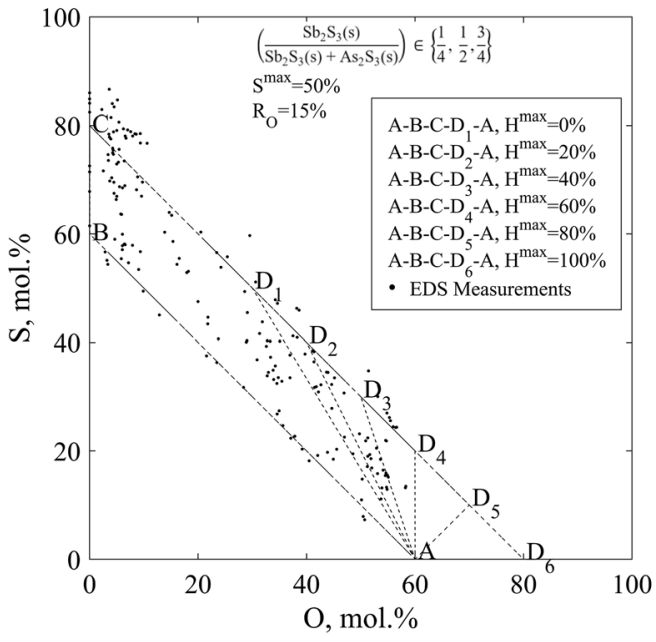

(a)

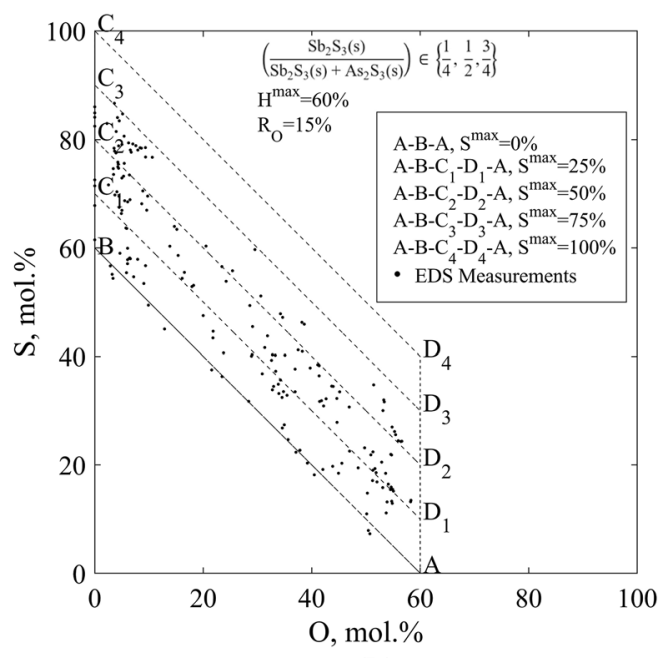

(b)

Fig. 14-Parametric analysis of the model performed by changing the input values for $(a) H^{\max }$ and $(b) S^{\max }$. The details of other input parameters are included in these plots of $\mathrm{S} v s$. O elemental compositions. These plots show only the modeled compositional limits obtained by bounding modeled random composition data points (not shown in the plots). The plotted data points are from the data of EDS measurements for the $350{ }^{\circ} \mathrm{C}$-condensate..

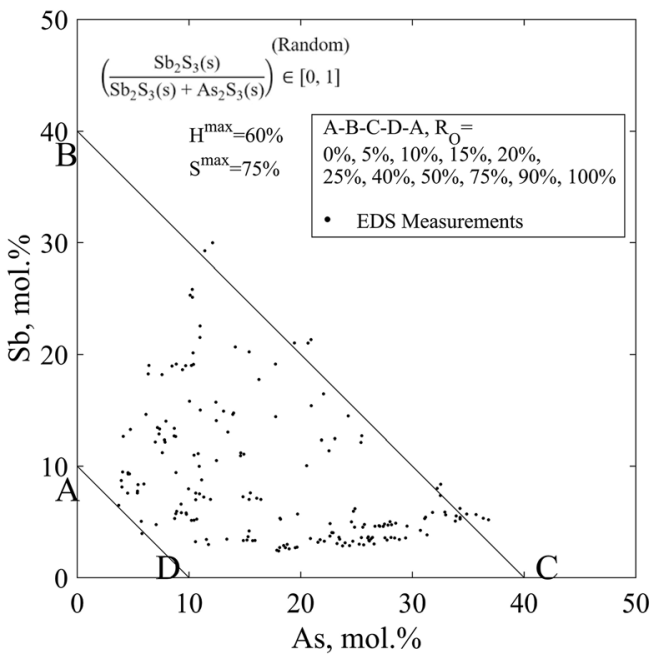

(a)

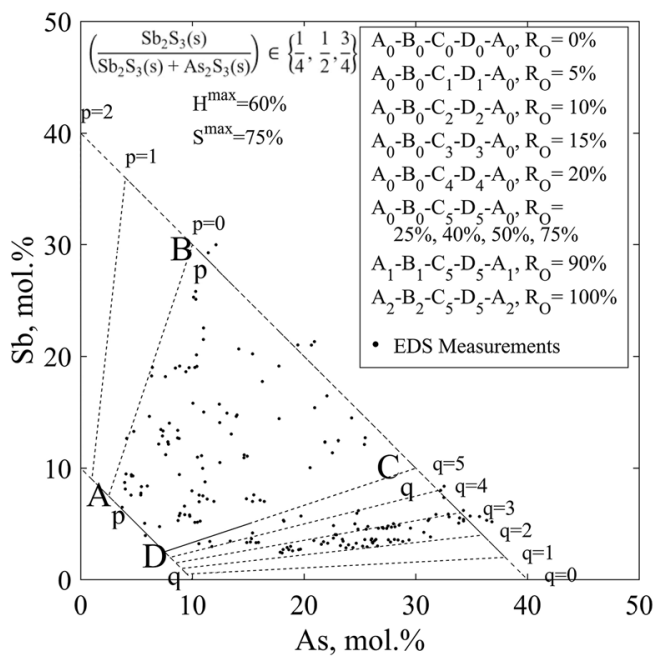

(b)

Fig. 15-Parametric analysis of the model by changing the input values of $R_{\mathrm{O}}$ and $(a)$ when Mode $=2$, i.e., considering that $\mathrm{Sb}_{2} \mathrm{~S}_{3}(\mathrm{~s})$ and $\mathrm{As}_{2} \mathrm{~S}_{3}(\mathrm{~s})$ condensed from the individual gaseous sulfides of $\mathrm{Sb}$ and $\mathrm{As} ;(b)$ when Mode $=1$, i.e., considering that $\mathrm{Sb}_{2} \mathrm{~S}_{3}(\mathrm{~s})$ and $\mathrm{As}_{2} \mathrm{~S}_{3}(\mathrm{~s})$ condensed from complex sulfide vapors $\mathrm{As}_{4-n} \mathrm{Sb}_{n} \mathrm{~S}_{6}(\mathrm{~g})$. Also, the data of EDS measurements for the $350{ }^{\circ} \mathrm{C}$-condensate superimposed..

boundary-ABCDA is obtained irrespective of the different input values of $R_{\mathrm{O}}=0,5,10,15,20,25,40,50$, 75, 90, and 100 mol pct. Also, the superimposed EDS measurements suggest that the modeled compositional limits obtained with Mode $=2$ are much wider than the scattered variations in the actual measurements. Interestingly, the modeled limits become responsive to the changes in $R_{\mathrm{O}}$ when Mode $=1$, as shown in Figure 15(b). The domain boundary obtained in each set of calculations is $\mathrm{A}_{p} \mathrm{~B}_{p} \mathrm{C}_{q} \mathrm{D}_{q} \mathrm{~A}_{p}$, where
- $p=0, q=0$ to 5 for $R_{\mathrm{O}} \leq 75 \mathrm{~mol} \mathrm{pct}$; and

$-p=1$ and $2, q=5$ for $R_{\mathrm{O}}>75 \mathrm{~mol}$ pct.

Evident from Figure 15(b), the EDS measurements are well confined by the modeled domain boundary $\mathrm{A}_{0} \mathrm{~B}_{0} \mathrm{C}_{2} \mathrm{D}_{2} \mathrm{~A}_{0} \quad(p=0$ and $q=2)$, corresponding to $R_{\mathrm{O}}=10 \mathrm{~mol}$ pct and Mode $=1$. The agreement between the modeled composition limit and the EDSin Figure 15(b) when Mode $=1$ points towards the existence of the complex sulfide species, $\mathrm{As}_{4-n} \mathrm{Sb}_{n} \mathrm{~S}_{6}(\mathrm{~g})$ in the gas phase during volatilization of $\mathrm{Sb}$ and $\mathrm{As}$ from 
Rockliden S7574 concentrate at $350{ }^{\circ} \mathrm{C}$. Additionally, it suggests $\frac{\mathrm{Sb}_{2} \mathrm{O}_{3}(\mathrm{~s})}{\mathrm{As}_{2} \mathrm{O}_{3}(\mathrm{~s})} \approx \frac{1}{9}$ (ratio calculated by putting $R_{\mathrm{O}}=10 \mathrm{~mol}$ pct in Eq. [2]) in the $350{ }^{\circ} \mathrm{C}$-condensate.

\section{Validation of Parametrized Inputs}

Table VII lists the values of the input variables of the stochastic model (described in Section VI-A) obtained through parametric analyses and subsequent comparison with the EDS measurements.

Until now, the $\mathrm{S} v s$. $\mathrm{O}$ and $\mathrm{As}$ vs. Sb graphical representations have been used to demonstrate the close agreements of the modeled composition limits and the EDS measurements. Figure 16 presents further validation of the modeled composition limits in the other four possible binary scatter plot representations-Sb vs. S, As vs. $\mathrm{S}, \mathrm{Sb}$ vs. $\mathrm{O}$, and $\mathrm{As}$ vs. O. These illustrations prove the consistency of the modeled results generated from the parametrized inputs in all the possible graphical representations for the condensate composed of $\mathrm{S}$, $\mathrm{O}, \mathrm{As}$, and $\mathrm{Sb}$.

Table VII. List of Parametrized Values for the Input Variables of the Stochastic Model

\begin{tabular}{lc}
\hline Input Variable & Parametrized Value \\
\hline$S^{\max }$ & $75 \mathrm{~mol} \mathrm{pct}$ \\
$H^{\max }$ & $60 \mathrm{~mol} \mathrm{pct}$ \\
Mode & 1 \\
$R_{\mathrm{O}}$ & $10 \mathrm{~mol} \mathrm{pct}$ \\
\hline
\end{tabular}

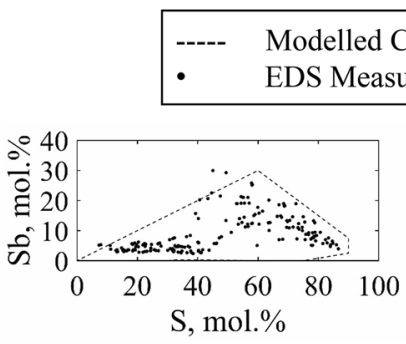

(a)

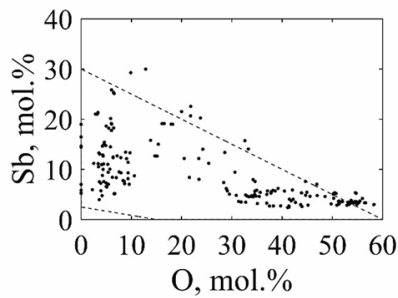

(c)

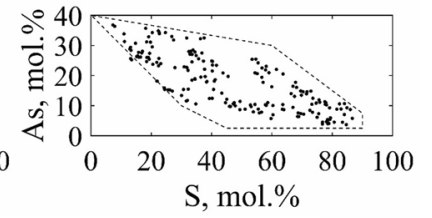

(b)

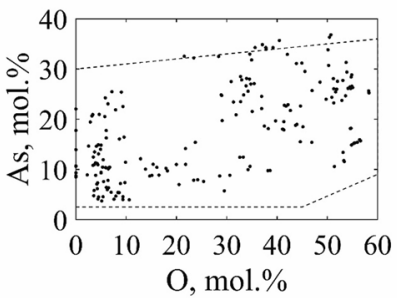

(d)
Fig. 16-Modeled composition limits obtained by running the stochastic model with parameterized inputs listed in Table VII in different graphical representations (a) Sb vs. S, (b) As vs. S, (c) Sb vs. $\mathrm{O}$, and $(d)$ As vs. O. EDS measurements superimposed.

\section{CONCLUSIONS}

Following conclusions can be drawn based on evaluation of the gas phase and solid-condensates collected during roasting of a $\mathrm{Cu}$-rich complex sulfide concentrate (containing $\mathrm{Sb}$ in the form of sulphosalts and gudmundite, and As mainly as arsenopyrite) in Nitrogen atmosphere carrying traces of oxygen $\left(\mathrm{p}^{\mathrm{O}_{2}} \approx 10^{-5.3}\right.$ bar):

1. The condensate collected at room temperature comprises of the following phases:

a. Elemental sulfur as cyclo-octa sulfur, $\mathrm{S}_{8}(\mathrm{~s})$; and polysulfur oxides, $\mathrm{S}_{n-x} \mathrm{O}_{x}(\mathrm{~s})$

b. Amorphous trisulfides of $\mathrm{Sb}$ and $\mathrm{As}: \mathrm{Sb}_{2} \mathrm{~S}_{3}(\mathrm{~s})$ and $\mathrm{As}_{2} \mathrm{~S}_{3}(\mathrm{~s})$

c. Cubic crystalline trioxides of $\mathrm{Sb}$ and As: $\mathrm{Sb}_{2} \mathrm{O}_{3}(\mathrm{cu}-$ bic) and $\mathrm{As}_{2} \mathrm{O}_{3}$ (cubic).

2. Volatilization of $\mathrm{Sb}$ involves interaction of metallic-Sb(s) (produced by thermal decomposition of gudmundite) with vapors of As-sulfides in the gas phase.

3. Thermodynamic analysis suggests that the Sb- and As-bearing compounds in the gas phase would mainly be their individual sulfides and oxides, and not their complex forms $\mathrm{As}_{4-n} \mathrm{Sb}_{n} \mathrm{X}_{6}(\mathrm{~g})(\mathrm{X}=\mathrm{O}, \mathrm{S}$ and $n=1,2,3)$. However, these thermodynamic assessments are not confirmatory for the complex sulfide phases (unlike for the complex oxides) owing to the lack of thermodynamic data for $\mathrm{As}_{3} \mathrm{SbS}_{6}(\mathrm{~g})$ and $\mathrm{As}_{2} \mathrm{Sb}_{2} \mathrm{~S}_{6}(\mathrm{~g})$. The equilibrium concentration of $\mathrm{AsSb}_{3} \mathrm{~S}_{6}(\mathrm{~g})$ (the only complex sulfide compound with available thermodynamic data) is much higher than those for all of the complex oxides- $\mathrm{As}_{4-n} \mathrm{Sb}_{n} \mathrm{O}_{6}(\mathrm{~g})$ $(n=1,2,3)$.

4. The solid phases in the condensate are fine-sized (sub-micronic) and widely intermixed leading to a heterogeneity in elemental composition of the condensates over different microscopic sites. Consequently, quantification of the solid phases in the condensates through direct measurement techniques like QEMSCAN is not possible.

5. A stochastic model-based computation of compositional limits can facilitate partial quantification of the solid phases in the condensate. Also, the model results can facilitate vital assessments regarding the complexation of $\mathrm{Sb}$ - and As-gaseous species. The following attributes of the condensate collected at $350{ }^{\circ} \mathrm{C}$ could be determined from the model:

a. The sulfur-content representing elemental sulfur, $\mathrm{S}_{n}(\mathrm{~s})$ (excluding sulphur in the $\mathrm{Sb}$ and As-sulfides), is below $75 \mathrm{~mol}$ pct at any site in the condensate.

b. The most oxidized polysulfur oxide in the condensate is $\mathrm{S}_{3} \mathrm{O}_{5}(\mathrm{~s})$.

c. The compositional limits in As vs. Sb mol pet representation obtained from the model closely confine the 
plotted points from the numerous EDS measurements. These modeled composition limits were calculated by considering the formation of $\mathrm{Sb}_{2} \mathrm{~S}_{3}(\mathrm{~s})$ and $\mathrm{As}_{2} \mathrm{~S}_{3}(\mathrm{~s})$ in the condensate only through the condensation of the complex sulfide vapors, $\mathrm{As}_{4-n} \mathrm{Sb}_{n} \mathrm{~S}_{6}(\mathrm{~g}) \quad(n=1, \quad 2,3)$. Therefore, the model results suggest the occurrence of vapor phase complexation of sulfides of $\mathrm{Sb}$ and As in the gas phase.

d. The condensate collected at room temperature during roasting of the complex concentrate at $350{ }^{\circ} \mathrm{C}$ has

a molar ratio of $\frac{\mathrm{Sb}_{2} \mathrm{O}_{3}(\mathrm{~s})}{\mathrm{As}_{2} \mathrm{O}_{3}(\mathrm{~s})} \approx \frac{1}{9}$. The relatively low content of $\mathrm{Sb}_{2} \mathrm{O}_{3}$ (s) compared to $\mathrm{As}_{2} \mathrm{O}_{3}$ (s) can be related to high condensation temperature of $\mathrm{Sb}_{2} \mathrm{O}_{3}(\mathrm{~s})$ of approx. $550{ }^{\circ} \mathrm{C}$ as against approx. $220{ }^{\circ} \mathrm{C}$ for $\mathrm{As}_{2} \mathrm{O}_{3}$ (s). By all accounts, most of the $\mathrm{Sb}_{2} \mathrm{O}_{3}(\mathrm{~s})$ escapes as suspended fines along with the gas phase.

\section{ACKNOWLEDGMENTS}

The authors thank (1) Swedish Strategic Innovation Program STRIM (a joint venture of Vinnova, Formas, and the Swedish Energy Agency) for the financial support; (2) personnel at Boliden Minerals AB for providing concentrate samples, chemical analyses, and QEMSCAN analyses; and (3) Ore Geology Division at Luleå Tekniska Universitet, Sweden for providing concentrate samples produced by them through laboratory-scale flotation in a previous study. The study is conducted within the context of $\mathrm{CAMM}^{2}$ (Center for Advanced Mining and Metallurgy) at Luleå University of Technology.

\section{FUNDING}

Open access funding provided by Lulea University of Technology.
Open Access This article is licensed under a Creative Commons Attribution 4.0 International License, which permits use, sharing, adaptation, distribution and reproduction in any medium or format, as long as you give appropriate credit to the original author(s) and the source, provide a link to the Creative Commons licence, and indicate if changes were made. The images or other third party material in this article are included in the article's Creative Commons licence, unless indicated otherwise in a credit line to the material. If material is not included in the article's Creative Commons licence and your intended use is not permitted by statutory regulation or exceeds the permitted use, you will need to obtain permission directly from the copyright holder. To view a copy of this licence, visit http://creativecommons. org/licenses/by/4.0/.

\section{APPENDIX 1: DETAILS OF THE THERMODYNAMIC CALCULATION IN FACTSAGE}

The thermodynamic data of $\mathrm{AsSb}_{3} \mathrm{~S}_{6}(\mathrm{~g})$ taken from HSC Chemistry into FactSage is presented below in Table A1.1.

Table A1.1. Thermodynamic Data of $\mathrm{AsSb}_{3} \mathrm{~S}_{6}(\mathrm{~g})$ Replicated from HSC Chemistry ${ }^{40]}$ into FactSage

\begin{tabular}{ll}
\hline Data Description & \multicolumn{1}{c}{ Value } \\
\hline Temperature Range, $\mathrm{K}$ & 298 to 2000 \\
Phase & Gaseous \\
$\Delta H^{298 \mathrm{~K}}, \mathrm{~kJ} / \mathrm{mol}$ & -85.379 \\
$S^{298 \mathrm{~K}}, \mathrm{~J} /(\mathrm{mol}-\mathrm{K})$ & 509.829 \\
$C_{\mathrm{p}}$ coefficient, A & 221.547 \\
$C_{\mathrm{p}}$ coefficient, B & 27.882 \\
$C_{\mathrm{p}}$ coefficient, C & -7.556 \\
$C_{\mathrm{p}}$ coefficient, D & 22.941 \\
\hline
\end{tabular}

$C_{\mathrm{p}}(\mathrm{T})=A+B \cdot T \cdot 10^{-3}+C \cdot \mathrm{T}^{-2} \cdot 10^{5}+D \cdot \mathrm{T}^{2} \cdot 10^{-6}$. 
Table A1.2Calculation of Initial Quantities of Reactants Commensurate with 1 Mole of Sb(s), as Input to the Thermodynamic Equilibrium Calculation

\begin{tabular}{|c|c|c|c|}
\hline Symbol & Value & Unit & Specific Data Used in the Calculation/Remarks \\
\hline $\mathrm{W}^{\text {conc }}$ & $4.27 \times 10^{4}$ & $\mathrm{~g} / \mathrm{mol}-\mathrm{Sb}$ & $\begin{array}{l}\text { 1. } 21 \mathrm{pct} \mathrm{Sb} \text {-deportment as gudmundite in the initial concentrate, from } \\
\text { Prasad } \text { et al. }{ }^{[2]} \\
\text { 2. } 1.36 \mathrm{wt} \text { pct } \mathrm{Sb} \text { in the initial concentrate, from Table I. }\end{array}$ \\
\hline$n_{\mathrm{N}_{2}(\mathrm{~g})}^{\text {initial }}$ & $4.57 \times 10^{4}$ & $\mathrm{~mol} / \mathrm{mol}-\mathrm{Sb}$ & $\begin{array}{l}\text { 1. } 2 \mathrm{~L} / \mathrm{min} \text { flow rate of carrier gas, from Table II, Experiment ID 350-10. } \\
\text { 2. } 10 \mathrm{~h} \text { duration of experiment at } 350{ }^{\circ} \mathrm{C} \text {, Table III, Experiment ID 350-10. } \\
\text { 3. } 50 \mathrm{~g} \text { weight of the initial concentrate, Table II, Experiment ID 350-10. }\end{array}$ \\
\hline$n_{\mathrm{O}_{2}(\mathrm{~g})}^{\text {initial }}$ & 0.23 & $\mathrm{~mol} / \mathrm{mol}-\mathrm{Sb}$ & $\begin{array}{l}\text { 1. Same as for } n_{\mathrm{N}_{2}(\mathrm{~g})}^{\text {initial }} \\
\text { 2. } 5 \mathrm{ppm} \text {, the upper limit of } \mathrm{O}_{2} \text { content in the carrier gas, Chemical Nitrogen } \\
\text { 4.6 }\end{array}$ \\
\hline$n_{\mathrm{H}_{2} \mathrm{O}(\mathrm{g})}^{\text {initial }}$ & 0.23 & $\mathrm{~mol} / \mathrm{mol}-\mathrm{Sb}$ & $\begin{array}{l}\text { 1. Same as for } n_{\mathrm{N}_{2}(\mathrm{~g})}^{\text {initial }} \text { limit of } \mathrm{H}_{2} \mathrm{O} \text { content in the carrier gas, Chemical } \\
\text { 2. } 5 \mathrm{ppm} \text {, the upper litrogen } 4.6\end{array}$ \\
\hline$n_{\mathrm{S}_{2}(\mathrm{~g})}^{\text {initial }}$ & 5.33 & $\mathrm{~mol} / \mathrm{mol}-\mathrm{Sb}$ & $\begin{array}{l}\text { 1. } 0.8 \text { pct weight loss of the concentrate in the TGA experiment, shown in } \\
\text { Figure } 5 \text {. It was assumed that the mass loss at } 350{ }^{\circ} \mathrm{C} \text { was essentially due } \\
\text { to volatilization of } \mathrm{S}_{2}(\mathrm{~g}) \text { from the concentrate. }\end{array}$ \\
\hline$n_{\mathrm{As}_{4} \mathrm{~S}_{4}(\mathrm{~g})}^{\text {initial }}$ & $10^{-21}$ to $10^{-15}$ & $\mathrm{~mol} / \mathrm{mol}-\mathrm{Sb}$ & 1. Study parameter, varied in a range of small values \\
\hline
\end{tabular}

The basis of input quantities to the thermodynamic model was 1 mole of $\mathrm{Sb}(\mathrm{s})$. Table A1.2 below lists the quantities of the initial reactants in the thermodynamic system commensurate with 1 mole of $\mathrm{Sb}(\mathrm{s})$.

\section{APPENDIX 2: STOCHASTIC MODEL FORMULATION}

Figure A2-1 presents a schematic representation of the stochastic model formulation, depicting the calculation approach in each run of the model. The solid phase constituents of the condensate are designated the following individual segments in a pie-chart, representing their molar proportions in the $350{ }^{\circ} \mathrm{C}$-condensate:

- Segment 1 -elemental sulphur $\left(\mathrm{S}_{n}\right)$ and solid polysulphur oxides $\left(\mathrm{S}_{n-x} \mathrm{O}_{x}\right)$

- Segment 2-the trisulfides, $\mathrm{As}_{2} \mathrm{~S}_{3}(\mathrm{~s})$ and $\mathrm{Sb}_{2} \mathrm{~S}_{3}(\mathrm{~s})$

- Segment 3-the trioxides, $\mathrm{As}_{2} \mathrm{O}_{3}$ (cubic) and $\mathrm{Sb}_{2} \mathrm{O}_{3}$ (cubic)

Based on the overall balance of elemental composition of the condensate in mol pct,

$$
\begin{aligned}
& n_{\mathrm{S}}^{\text {extra }}+n_{\mathrm{O}}^{\text {extra }}+n_{\mathrm{S}}^{\mathrm{sul}(\mathrm{As}, \mathrm{Sb})}+n_{\mathrm{O}}^{\mathrm{ox}(\mathrm{As}, \mathrm{Sb})}+n_{\mathrm{Sb}}^{\mathrm{sul}}+n_{\mathrm{As}}^{\mathrm{sul}}+n_{\mathrm{Sb}}^{\mathrm{ox}} \\
& \quad+n_{\mathrm{As}}^{\mathrm{ox}} \\
& \quad=100 \text { pct }
\end{aligned}
$$$$
[\mathrm{A} 2-1]
$$

The extra sulphur (excluding $\mathrm{S}$ in $\mathrm{Sb}_{2} \mathrm{~S}_{3}(\mathrm{~s})$ and $\left.\mathrm{As}_{2} \mathrm{~S}_{3}(\mathrm{~s})\right)$ can be between 0 to $S^{\mathrm{max}}$ mol pct in the condensate (its proportion in the condensate can be mathematically expressed as $p_{1} S^{\max }$, as shown in Figure A2-1, where $\left.p_{1} \in[0,1]\right)$. Secondly, any extra oxygen (excluding $\mathrm{O}$ in $\mathrm{Sb}_{2} \mathrm{O}_{3}$ and $\mathrm{As}_{2} \mathrm{O}_{3}$ ) would be part of solid sulphur oxides, $\mathrm{S}_{n-x} \mathrm{O}_{x}(\mathrm{~s})$ formed via Reaction [3]. Since the model assumes equal substitution of $S$ atoms by $\mathrm{O}$ atoms (based on the slope of -1 for the line
CD Figure 9), the sum of the molar quantities of $\mathrm{S}_{n}(\mathrm{~s})$ and $\mathrm{S}_{n-x} \mathrm{O}_{x}(\mathrm{~s})$ in the condensate will not change due to the occurrence of Reaction [3], Therefore,

$$
n_{\mathrm{S}}^{\text {extra }}+n_{\mathrm{O}}^{\text {extra }}=\mathrm{p}_{1} \times S^{\max }
$$

Since the oxygen content in $\mathrm{S}_{n-x} \mathrm{O}_{x}(\mathrm{~s})$ is between 0 to $H^{\mathrm{max}}$, its composition can be visualized in a subsidiary pie-chart elaborating the chemical composition of the constituents in Segment 1 in Figure A2-1 (PIP chart 1). The relationship can be mathematically expressed as

$$
n_{\mathrm{O}}^{\text {extra }}=\mathrm{p}_{1} \times S^{\max } \times \mathrm{p}_{2} \times H^{\max } / 100 \quad[\mathrm{~A} 2-3]
$$

And using Eq. [A2-2],

$$
\begin{array}{r}
n_{\mathrm{S}}^{\text {extra }}=\mathrm{p}_{1} \times S^{\max }-\mathrm{p}_{1} \times S^{\max } \times \mathrm{p}_{2} \times H^{\max } 100 \\
{[\mathrm{~A} 2-4]}
\end{array}
$$

Other than $\mathrm{S}_{n}(\mathrm{~s})$ and $\mathrm{S}_{n-x} \mathrm{O}_{x}(\mathrm{~s})$, the condensate has the trisulfides $\mathrm{Sb}_{2} \mathrm{~S}_{3}(\mathrm{~s})-\mathrm{As}_{2} \mathrm{~S}_{3}(\mathrm{~s})$ and the oxides $\mathrm{Sb}_{2} \mathrm{O}_{3}(-$ $\mathrm{s})-\mathrm{As}_{2} \mathrm{O}_{3}(\mathrm{~s})$, which would bear the following stoichiometric relationships:

$$
\frac{n_{\mathrm{As}}^{\mathrm{sul}}+n_{\mathrm{Sb}}^{\mathrm{sul}}}{n_{\mathrm{S}}^{\mathrm{sul}(\mathrm{As}, \mathrm{Sb})}}=\frac{2}{3}
$$

and,

$$
\frac{n_{\mathrm{As}}^{\mathrm{ox}}+n_{\mathrm{Sb}}^{\mathrm{ox}}}{n_{\mathrm{O}}^{\mathrm{ox}(\mathrm{As}, \mathrm{Sb})}}=\frac{2}{3}
$$

The sum of the moles of trioxides and trisulfides of As and $\mathrm{Sb}$ would be $\left(1-\mathrm{p}_{1} S^{\max }\right)$. Also, the ratio of sulfide to oxide forms of $\mathrm{As}$ and $\mathrm{Sb}$ in the condensate can be random, i.e., $\frac{\mathrm{p}_{3}}{\left(1-\mathrm{p}_{3}\right)}$, as specified in Segment 2 and Segment 3 in Figure A2-1. Accordingly, the total moles of trioxides will be $\mathrm{p}_{3}\left(1-\mathrm{p}_{1} S^{\max }\right)$, and the total moles of trisulfides will be $\left(1-p_{3}\right)\left(1-p_{1} S^{\max }\right)$. Subsequently, the 


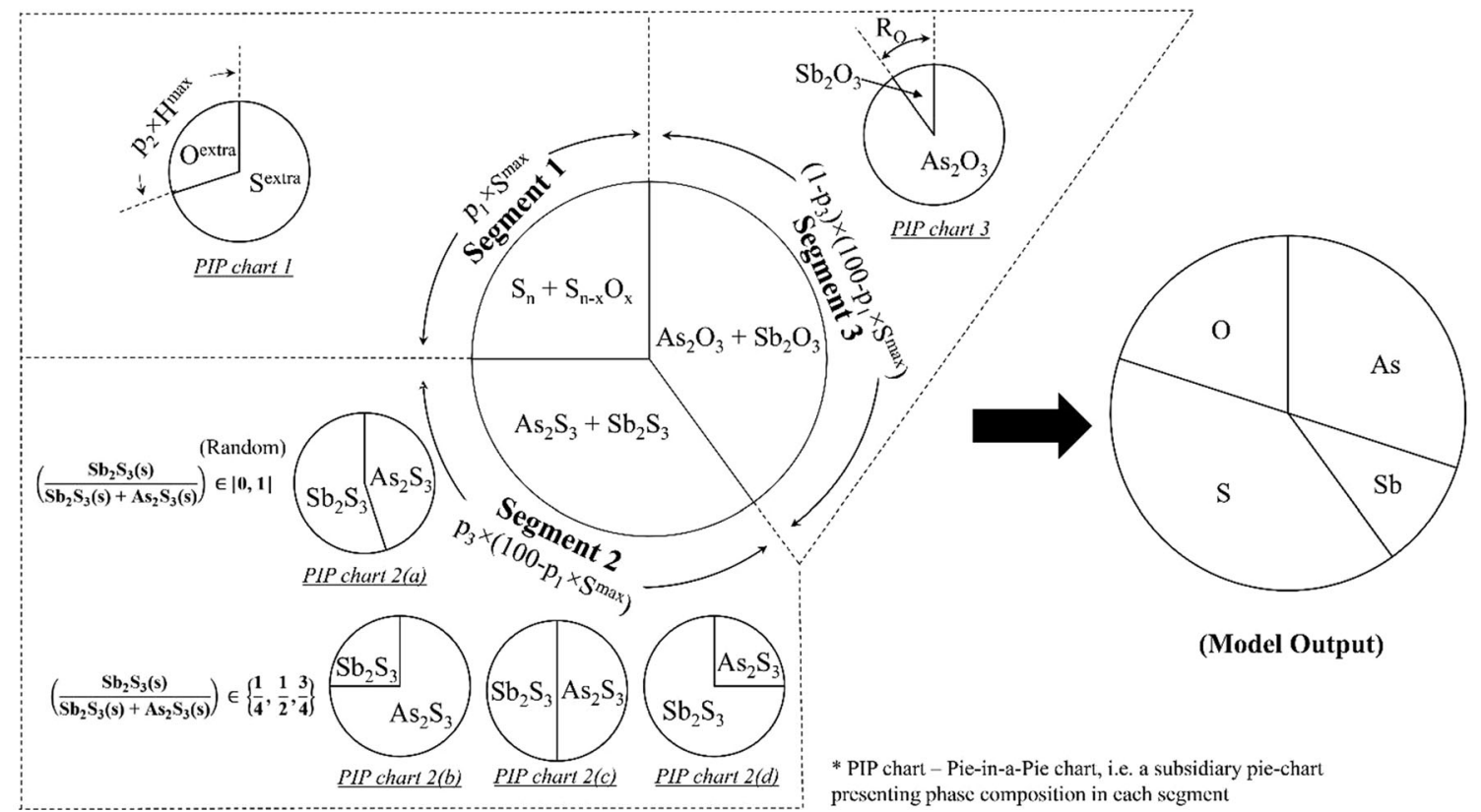

Fig. A2-1 - Stochastic model formulation depicting the relevance of input parameters and demonstrating the incorporation of random numbers $p_{1}, p_{2}, p_{3}$ in the calculation. The model calculates elemental composition of the condensate (shown as a model output in the pie-chart on the right). Composition values are in mol pet.

following equations related to the quantities of elements in the trioxides and trisulfides can be derived using Eqs. [A2-2] to [A2-6].

$$
\begin{gathered}
n_{\mathrm{As}}^{\text {sul }}+n_{\mathrm{Sb}}^{\text {sul }}=0.4 \times \mathrm{p}_{3} \times\left(100-n_{\mathrm{S}}^{\text {extra }}-n_{\mathrm{O}}^{\text {extra }}\right)[\mathrm{A} 2-7] \\
n_{\mathrm{S}}^{\text {sul( }(\mathrm{As}, \mathrm{Sb})}=0.6 \times \mathrm{p}_{3} \times\left(100-n_{\mathrm{S}}^{\text {extra }}-n_{\mathrm{O}}^{\text {extra }}\right)[\mathrm{A} 2-8] \\
n_{\mathrm{As}}^{\text {ox }}+n_{\mathrm{Sb}}^{\text {ox }}=0.4 \times\left(1-\mathrm{p}_{3}\right) \times\left(100-n_{\mathrm{S}}^{\text {extra }}-n_{\mathrm{O}}^{\text {extra }}\right)
\end{gathered}
$$$$
[\text { A2 - 9] }
$$$$
n_{\mathrm{O}}^{\mathrm{ox}(\mathrm{Ass}, \mathrm{Sb})}=0.6 \times\left(1-\mathrm{p}_{3}\right) \times\left(100-n_{\mathrm{S}}^{\mathrm{extra}}-n_{\mathrm{O}}^{\mathrm{extra}}\right)
$$

The ratio of $\mathrm{Sb}_{2} \mathrm{~S}_{3}$ to $\mathrm{As}_{2} \mathrm{~S}_{3}$ in the condensate can be mathematically expressed as $\frac{\mathrm{p}_{4}}{\left(1-\mathrm{p}_{4}\right)}$ by introducing another random number $\mathrm{p}_{4}$. The assignment of $\mathrm{p}_{4}$ is based on the value of the input parameter-Mode:

- In case of Mode $=1$, the trisulfides of $\mathrm{Sb}$ and $\mathrm{As}$ are considered to condense from their complex sulfide vapors, $\mathrm{As}_{n-x} \mathrm{Sb}_{x} \mathrm{~S}_{6}(\mathrm{~g})$, such that $\mathrm{p}_{4} \in\left\{\frac{1}{4}, \frac{1}{2}, \frac{3}{4}\right\}$ (Table VI). One value from this set is selected randomly in each calculation run (graphical representations of this case are in PIP-charts 2(b)-2(d) in Figure A2-1).
- When Mode $=2, \mathrm{p}_{4}$ is a random number between 0 to 1 (PIP chart 2(a)), which implies that the condensation of trisulfides of $\mathrm{Sb}$ and $\mathrm{As}$ are not from the complex sulfide vapors, but instead from their individual sulfide vapor phases.

Accordingly, using Eq. [A2-7],

$$
\begin{gathered}
n_{\mathrm{Sb}}^{\mathrm{sul}}=0.4 \times \mathrm{p}_{4} \times \mathrm{p}_{3} \times\left(100-n_{\mathrm{S}}^{\mathrm{extra}}-n_{\mathrm{O}}^{\mathrm{extra}}\right)[\mathrm{A} 2-11] \\
n_{\mathrm{As}}^{\text {sul }}=0.4 \times\left(1-p_{4}\right) \times \mathrm{p}_{3} \times\left(100-n_{\mathrm{S}}^{\mathrm{extra}}-n_{\mathrm{O}}^{\text {extra }}\right)
\end{gathered}
$$

The proportion of $\mathrm{Sb}_{2} \mathrm{O}_{3}$ to $\mathrm{As}_{2} \mathrm{O}_{3}$ in the condensate is calculated based on the value of the input parameter $R_{\mathrm{O}}$. Therefore, using Eq. [A2-9],

$$
\begin{aligned}
n_{\mathrm{Sb}}^{\mathrm{ox}}=0.4 & \times \frac{R_{\mathrm{O}}}{100} \times\left(1-p_{3}\right) \times\left(100-n_{\mathrm{S}}^{\text {extra }}-n_{\mathrm{O}}^{\text {extra }}\right) \\
{[\mathrm{A} 2-13] } & \\
n_{\mathrm{As}}^{\mathrm{ox}}= & 0.4 \times\left(1-\frac{R_{\mathrm{O}}}{100}\right) \times\left(1-p_{3}\right) \\
& \times\left(100-n_{\mathrm{S}}^{\text {extra }}-n_{\mathrm{O}}^{\text {extra }}\right)
\end{aligned}
$$

Using Eqs. [A2-4] to [A2-5], [A2-8], [A2-10] to [A2-14], the values of $n_{\mathrm{S}}^{\text {extra }}, n_{\mathrm{O}}^{\text {extra }}, n_{\mathrm{S}}^{\text {sul }(\mathrm{As}, \mathrm{Sb})}, n_{\mathrm{O}}^{\mathrm{ox}(\mathrm{As}, \mathrm{Sb})}, n_{\mathrm{Sb}}{ }^{\mathrm{sul}}, n_{\mathrm{As}}^{\mathrm{sul}}, n_{\mathrm{Sb}}^{\mathrm{ox}}, n_{\mathrm{As}}^{\text {ox }}$ are calculated. The moles of individual elements are calculated using the following equations: 


$$
\begin{array}{cc}
n_{\mathrm{O}}=n_{\mathrm{O}}^{\mathrm{extra}}+n_{\mathrm{O}}^{\mathrm{ox}(\mathrm{As}, \mathrm{Sb})} & {[\mathrm{A} 2-15]} \\
n_{\mathrm{S}}=n_{\mathrm{S}}^{\mathrm{extra}}+n_{\mathrm{S}}^{\mathrm{sul}(\mathrm{As}, \mathrm{Sb})} & {[\mathrm{A} 2-16]} \\
n_{\mathrm{As}}=n_{\mathrm{As}}^{\mathrm{sul}}+n_{\mathrm{As}}^{\mathrm{ox}} & {[\mathrm{A} 2-17]} \\
& \\
n_{\mathrm{Sb}}=n_{\mathrm{Sb}}^{\mathrm{sul}}+n_{\mathrm{Sb}}^{\mathrm{ox}} & {[\mathrm{A} 2-18]}
\end{array}
$$

\begin{tabular}{|c|c|}
\hline$m / e$ & Mass-to-charge ratio \\
\hline & $\begin{array}{l}\text { Weight of concentrate containing } 1 \text { mole } \\
\text { of } \mathrm{Sb} \text { in the form of gudmundite, } \mathrm{g} / \mathrm{mol}-\mathrm{Sb}\end{array}$ \\
\hline$n_{\mathrm{N}_{2}(\mathrm{~g})}^{\text {initial }}$ & $\begin{array}{l}\mathrm{N}_{2}(\mathrm{~g}) \text { introduced per mol of } \mathrm{Sb}(\mathrm{s}) \\
\text { produced from gudmundite } \\
\text { decomposition, mol } / \text { mol-Sb }\end{array}$ \\
\hline$n_{\mathrm{O}_{2}(\mathrm{~g})}^{\text {initial }}$ & $\begin{array}{l}\mathrm{O}_{2}(\mathrm{~g}) \text { introduced per mol of } \mathrm{Sb}(\mathrm{s}) \\
\text { produced from gudmundite } \\
\text { decomposition, mol/mol-Sb }\end{array}$ \\
\hline$n_{\mathrm{H}_{2} \mathrm{O}(\mathrm{g})}^{\text {initial }}$ & $\begin{array}{l}\mathrm{H}_{2} \mathrm{O}(\mathrm{g}) \text { introduced per mol of } \mathrm{Sb}(\mathrm{s}) \\
\text { produced from gudmundite } \\
\text { decomposition, mol/mol-Sb }\end{array}$ \\
\hline$n_{\mathrm{S}_{2}(\mathrm{~g})}^{\text {initial }}$ & $\begin{array}{l}\mathrm{S}_{2}(\mathrm{~g}) \text { introduced per mol of } \mathrm{Sb}(\mathrm{s}) \\
\text { produced from gudmundite } \\
\text { decomposition, mol/mol-Sb }\end{array}$ \\
\hline$n_{\mathrm{As}_{4} \mathrm{~S}_{4}(\mathrm{~g})}^{\text {initial }}$ & $\begin{array}{l}\mathrm{As}_{4} \mathrm{~S}_{4}(\mathrm{~g}) \text { introduced per mol of } \mathrm{Sb}(\mathrm{s}) \\
\text { produced from gudmundite } \\
\text { decomposition, mol/mol-Sb }\end{array}$ \\
\hline$n_{\mathrm{S}}^{\text {extra }}$ & $\begin{array}{l}\text { Sulphur content corresponding to } \mathrm{S}_{n}(\mathrm{~s}) \\
\text { and } \mathrm{S}_{n-x} \mathrm{O}_{x}(\mathrm{~s}) \text { in the condensate, mol pct }\end{array}$ \\
\hline$n_{\mathrm{O}}^{\text {extra }}$ & $\begin{array}{l}\text { Oxygen content corresponding to } \mathrm{S}_{n-x} \\
\mathrm{O}_{x}(\mathrm{~s}) \text { in the condensate, mol pct }\end{array}$ \\
\hline $\mathrm{p}_{i=1,2,3}$ & $\begin{array}{l}\text { Uniformly distributed random number } \epsilon \\
{[0,1] \text { generated at different stages in each }} \\
\text { run of calculation }\end{array}$ \\
\hline $\mathrm{p}_{4}$ & $\begin{array}{l}\text { A randomly selected number from the set } \\
\{0.25,0.5,0.75\} \text { when Mode }=1 \text {; a } \\
\text { random number } \epsilon[0,1] \text { when Mode }=2\end{array}$ \\
\hline$n_{\mathrm{S}}^{\mathrm{sul}(\mathrm{As}, \mathrm{Sb})}$ & $\begin{array}{l}\text { Sulphur content corresponding to } \mathrm{As}_{2} \mathrm{~S}_{3}(\mathrm{~s}) \\
\text { and } \mathrm{Sb}_{2} \mathrm{~S}_{3}(\mathrm{~s}) \text { in the condensate, mol pct }\end{array}$ \\
\hline$n_{\mathrm{O}}^{\mathrm{ox}(\mathrm{As}, \mathrm{Sb})}$ & $\begin{array}{l}\text { Oxygen content corresponding to } \mathrm{As}_{2} \mathrm{O}_{3}(\mathrm{~s}) \\
\text { and } \mathrm{Sb}_{2} \mathrm{O}_{3}(\mathrm{~s}) \text { in the condensate, mol pct }\end{array}$ \\
\hline$n_{\mathrm{Sb}}^{\mathrm{sul}}$ & $\begin{array}{l}\text { Antimony content corresponding to } \\
\mathrm{Sb}_{2} \mathrm{~S}_{3}(\mathrm{~s}) \text { in the condensate, mol pct }\end{array}$ \\
\hline$n_{\mathrm{As}}^{\mathrm{sul}}$ & $\begin{array}{l}\text { Arsenic content corresponding to } \mathrm{As}_{2} \mathrm{~S}_{3}(\mathrm{~s}) \\
\text { in the condensate, mol pct }\end{array}$ \\
\hline$n_{\mathrm{Sb}}^{\mathrm{OX}}$ & $\begin{array}{l}\text { Antimony content corresponding to } \\
\mathrm{Sb}_{2} \mathrm{O}_{3}(\mathrm{~s}) \text { in the condensate, mol pct }\end{array}$ \\
\hline
\end{tabular}

Finally, the elemental composition in mol pct is derived using the below expression:

$$
\mathrm{X}_{\mathrm{i}}=\frac{n_{\mathrm{i}}}{\sum n_{i}} \times 100, i=\mathrm{O}, \mathrm{S}, \mathrm{As}, \mathrm{Sb} \quad[\mathrm{A} 2-19]
$$

\section{LIST OF SYMBOLS}

$n_{\mathrm{As}}^{\mathrm{ox}} \quad$ Arsenic content corresponding to $\mathrm{As}_{2} \mathrm{O}_{3}(\mathrm{~s})$ in the condensate, mol pct

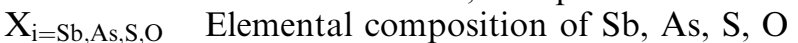
calculated from the model in each run, mol pct

\section{REFERENCES}

1. T. Li and J.P. Hager: in Reinhardt Schuhmann Int. Symp. Innovative Technol. React. Des. Extr. Metall., Proc. Symp., D.R. Gaskell, J.P. Hager, J.E. Hoffmann, and P.J. Mackey, eds., 1986, pp. 845-68.

2. J.E. Mauser: Metall. Trans. B, 1982, vol. 13, pp. 511-13.

3. J.W. Hastie and J.P. Hager: in Elliott symp. proc., P. Koros and G. StPierre, eds., Iron Steel Soc., Warrendale, PA, 1990, pp. 301-24.

4. G.A. Brooks, W.J. Rankin, and N.B. Gray: Metall. Mater. Trans. $B, 1994$, vol. 25B, pp. 873-84.

5. D.P. Zhong, L. Li, and C. Tan: Metall. Mater. Trans. B, 2017, vol. 48 , pp. $1308-14$.

6. L. Li, F. Wang, D. Zhong, C. Tan, and Y. Yu: ISIJ Int., 2017, vol. 57, pp. 581-86.

7. M Xu, L Li, and KX Mao: ACS Omega, 2019, vol. 4, pp. 69686976.

8. C. Tan, L. Li, K. Li, and D. Zhong: Sep. Purif. Technol., 2018, vol. 194 , pp. $81-88$

9. J.H. Norman and H.G. Staley: J. Chem. Phys., 1964, vol. 41, pp. 1503-04.

10. J. Drowart, S. Smoes, and A. Vanderauwera-Mahieu: J. Chem. Thermodyn., 1978, vol. 10, pp. 453-64.

11. B. Westphal: Thesis, T-3778, Colorado School of Mines, 1989.

12. H. Jalkanen and E. Andersin: in Proc. Int. Terkel Rosenqvist Symp., S.E. Olsen and J.K. Tuset, eds., Norw. Inst. Technol., Trondheim, 1988, pp. 323-39.

13. S. Nakazaw, A. Yazawa, and F.R.A. Jorgensen: MetallMater. Trans. B, 1999, vol. 30 (3), pp. 393-401.

14. G. Lindkvist and A. Holmstrom: in Adv. Sulfide Smelting, Proc. Int. Sulfide Smelting Symp. Extr. Process Metall. Meet. Metall. Soc. AIME, vol. 2, H.Y. Sohn, D.B. George, and Zunkel A D, eds., TMS-AIME, Warrendale, PA, 1983, pp. 451-73.

15. A.T. Jokilaakso, P.A. Taskinen, R.O. Suominen, and K.R. Lilius: Scand. J. Metall., 1994, vol. 23, pp. 54-61.

16. W. Hong Lu and Z. lan Yin: Int. J. Miner. Process., 2016, vol. 153, pp. $1-7$.

17. S. Shibuya, C. Tokoro, and T. Okura: in Proc. 7th Eur. Metall. Conf., 2013, pp. 111-22.

18. A. Holmström: Ph.D. Thesis, R. Inst. Technol., Dep. Prod. Technol. (Stockholm), 1988.

19. K. Haga, B. Altansukh, and A. Shibayama: Mater. Trans., 2018, vol. 59, pp. 1396-1403.

20. I. Wilkomirsky, F. Parada, A. Ulloa, A. Carrasso, and L. Jeraldo: in Proc. IV Int. Conf. Clean Technol. Min. Ind., vol. 2, Concepción Univ. Press, 1998, pp. 613-21.

21. R. Padilla and M.C. Ruiz: in Drying, Roasting, Calcining Miner., T. Battle, J. Downey, L. May, B. Davis, N. Neelameggham, S. Sanchez-Segado, and C. Pistorius, eds., Springer Int. Publishing, 2016, pp. 43-50.

22. I. Wilkomirsky, R. Parra, F. Parada, and E. Balladares: in COM 2014 - Conf. Metall. Proc., B. Davis, ed., Metall. Mater. Soc., Can. Inst. Min, Metall. Pet., 2014.

23. G. Majumdar, A.E. Morris, and M. Wadsley: Met. Extr.: Phase Stab. Diagrams, Ref. Module Mater. Sci. Mater. Eng., Elsevier, 2016.

24. P.N. Prasad, I. McElroy, A. Lennartsson, and C. Samuelsson: Metall. Mater. Trans. B, 2021, vol. 52, pp. 764-77.

25. P.R. Taylor and T.A.R. Putra: in Celebrating Megascale, Proc. Extr. Process. Div. Symp. Pyrometall., P.J. Mackey, E.J. Grimsey, R.T. Jones, and G.A. Brooks, eds., John Wiley \& Sons, Inc., 2014, pp. 197-211.

26. F. Minz, N.-J. Bolin, P. Lamberg, and C. Wanhainen: Miner. Eng., 2013, vol. 52, pp. 95-103.

27. P.N. Prasad, A. Lennartsson, and C. Samuelsson: Metall. Mater. Trans. B, 2020, vol. 51, pp. 1446-59.

28. SS EN ISO 17294-2, Swed. Stand., Eur. Comm. Stand., 2016. 
29. S.E. Long and T.D. Martin: EPA Method 200.8, U.S. Environ. Prot. Agency, 1994.

30. HM Ahmed, A Persson, LS Ökvist, and B Björkman: ISIJ Int., 2015, vol. 55 (10), pp. 2082-89.

31. P.B.T.-P.M. BalÁž, ed.: in Extr. Metall. Act. Miner., vol. 10, Elsevier, 2000, pp. 95-142.

32. J.B.W. Webber: Meas. Sci. Technol., 2012, vol. 24, p. 27001.

33. S. Tamura, H. Sugimoto, and M. Yashima: in AIP Conf. Proc., vol. 2132, 2019, pp. 190007:1-190007:12.

34. R. Steudel, F.C. Nachod and J.J. Zuckerman, eds., Engl., Walter de Gruyter, Berlin, 1977, p. 216.

35. L Komorova, A Holmstrom, and I Imris: Scand. J. Metall., 1985, vol. 14, pp. 103-12.
36. K.E. Haque: in Proc. Metall. Soc. Can. Inst. Min. Metall., R.S. Salter, D.M. Wyslouzil, and G.W. McDonald, eds., Elsevier, 1987, pp. $327-39$.

37. L. Marton and C. Marton, eds.: in Adv. Electron. Electron Phys., Academic Press, New York, 1959, p. 379.

38. F.W. Glaze, D.H. Blackburn, J.S. Osmalov, D. Hubbard, and M.H. Black: J. Res. Natl. Bur. Stand. (1934)., 1957, vol. 59, pp. 83-92.

39. FactSage 7.3: @ CRCT - Thermfact Inc. and GTT - Technologies. 40. HSC Chemistry 9: (c) Outotec Oy-Finland.

Publisher's Note Springer Nature remains neutral with regard to jurisdictional claims in published maps and institutional affiliations. 